\title{
AMPA and NMDA Glutamate Receptor Subunits in Midbrain Dopaminergic Neurons in the Squirrel Monkey: An Immunohistochemical and In Situ Hybridization Study
}

\author{
Maryse Paquet, ${ }^{1,2}$ Martine Tremblay, ${ }^{1}$ Jean-Jacques Soghomonian, ${ }^{1}$ and Yoland Smith ${ }^{1,2}$ \\ ${ }^{1}$ Centre de Recherche en Neurobiologie, Hôpital de l'Enfant-Jésus, Université Laval, Québec, Canada G1J 1Z4, and \\ 2Division of Neuroscience, Yerkes Primate Center and Department of Neurology, Emory University, Atlanta, \\ Georgia 30322
}

\begin{abstract}
The objective of the present study was to analyze the cellular and subcellular localization of ionotropic glutamate receptor subunits in midbrain dopaminergic neurons in the squirrel monkey. This was achieved by means of immunohistochemistry at light and electron microscopic levels and in situ hybridization histochemistry.

Colocalization studies show that nearly all dopaminergic neurons in both the ventral and dorsal tiers of the substantia nigra compacta (SNc-v, SNc-d) and the ventral tegmental area (VTA) are immunoreactive for AMPA (GluR1, GluR2/3, and GluR4) and NMDAR1 receptor subunits, but not for NMDAR2A/B subunits. The immunoreactivity of the receptor subunits is associated mainly with perikarya and dendritic shafts. Apart from the intensity of immunolabeling for the GluR4 subunit, which is quite similar for the different groups of midbrain dopaminergic neurons, the overall intensity of immunostaining for the other subunits is higher in the SNc-v and SNc-d than in the VTA. In line with these observations, in situ hybridization shows that the average level of labeling for the GluR2 and NMDAR1 subunit mRNAs is significantly higher in the SNc-v than in the VTA, and for the NMDAR1 subunit, higher in the SNc-v than in the SNc-d.
\end{abstract}

In contrast, no significant difference was found for the level of GluR1 mRNA labeling among the three groups of midbrain dopaminergic neurons. At the subcellular level in the SNc-v, AMPA (GluR1 and GluR2/3) and NMDAR1 receptor subunit immunoreactivity is preferentially associated with the postsynaptic densities of asymmetric synapses, but occasionally some immunoreactivity is found along nonsynaptic portions of plasma membranes of dendrites. A small number of preterminal axons, axon terminals, and glial cell processes are also immunoreactive.

Our observations indicate that the different groups of midbrain dopaminergic neurons in primates exhibit a certain degree of heterogeneity with regard to the level of expression of some ionotropic glutamate receptor subunits. The widespread neuronal and glial localization of glutamate receptor subunits suggests that excitatory amino acids may act at different levels to control the basal activity and, possibly, to participate in the degeneration of midbrain dopaminergic neurons in Parkinson's disease.

Key words: excitotoxicity; Parkinson's disease; substantia nigra; ventral tegmental area; dopamine; glutamate receptor
Although glutamatergic afferents play a major role in the control of the basal activity of midbrain dopaminergic neurons (Grace and Bunney, 1984; Gariano and Groves, 1988; Grenhoff et al., 1988; Charlety et al., 1991; Smith and Grace, 1992; Chergui et al., 1994; Tong et al., 1996), glutamate also may be neurotoxic to dopaminergic neurons and may participate in their degeneration in Parkinson's disease (Beal, 1992a,b; Johnson et al., 1992; Kikuchi and Kim, 1993; Marey-Semper et al., 1995; Blandini et al., 1996). The fact that midbrain dopaminergic neurons immunoreactive for the calcium-binding protein calbindin- $\mathrm{D}_{28 \mathrm{~K}}$ are selectively spared in Parkinson's disease (Yamada et al., 1990; Lavoie and Parent, 1991; Iacopino et al., 1992; Ito et al., 1992) indicates that an overload of calcium may underlie the neurodegenerative processes.

The excitatory effects of glutamate are mediated through the

Received July 11, 1996; revised Oct. 4, 1996; accepted Dec. 3, 1996

This research was supported by the Canadian Foundation of Parkinson's Disease and the Fonds de la Recherche en Santé du Québec as well as by the Department of Neurology and the Yerkes Primate Center of Emory University. Maryse Paquet holds a studentship from the Medical Research Council of Canada. We thank Jean-François Paré and Isabelle Deaudelin for their excellent technical assistance.

Correspondence should be addressed to Yoland Smith, Yerkes Regional Primate Center, Emory University, 954 Gatewood Road NE, Atlanta, GA 30341.

Copyright (C) 1997 Society for Neuroscience 0270-6474/97/171377-20\$05.00/0 activation of ionotropic and metabotropic receptors. The ionotropic receptors represent glutamate-gated cation channels and are divided into two major classes by their pharmacological properties, namely the NMDA receptors and the AMPA-kainate receptors. Recent developments in molecular biology have greatly advanced our understanding of the structure, properties, and expression of glutamate receptors (Gasic and Hollmann, 1992; Nakanishi, 1992; Hollmann and Heinemann, 1994; Westbrook, 1994). Numerous subunits and variants constituting the different types of glutamate receptors have now been cloned and sequenced. Various factors, including the subunit composition and the relative abundance of these subunits, influence the $\mathrm{Ca}^{+2}$ permeability and desensitization of the receptor complex, two critical events involved in excitotoxicity (Burnashev et al., 1992; Nakanishi, 1992; Hollmann and Heinemann, 1994; Jonas et al., 1994; Trussell et al., 1994; Geiger et al., 1995; Jonas and Burnashev, 1995).

The subunit composition of the AMPA and NMDA receptors associated with midbrain dopaminergic neurons therefore may underlie the susceptibility of these neurons to degenerate in Parkinson's disease. To further our knowledge on this issue, we undertook a detailed analysis of the cellular and subcellular localization of AMPA and NMDA receptor subunits in the substan- 
tia nigra compacta (SNc) and ventral tegmental area (VTA) in the squirrel monkey. Because the dopaminergic neurons in the VTA are less vulnerable than those in the SNc in Parkinson's disease (Yamada et al., 1990), the first two objectives of our study were to (1) compare the pattern of immunoreactivity for glutamate receptor subunit in SNc and VTA and (2) quantify the relative abundance of the mRNAs encoding for these subunits. To understand better the synaptic organization as well as the role of glia in the functional interactions between glutamate and midbrain dopaminergic neurons, another objective was to analyze the subcellular localization of the different glutamate receptor subunits in the SNc. This study was achieved by light and electron microscopic immunocytochemistry and the radioautographic in situ hybridization method.

The results of this study have been published previously in abstract form (Paquet et al., 1995).

\section{MATERIALS AND METHODS Immunocytochemistry} Animals and preparation of tissue

Three adult male squirrel monkeys (Saimiri sciureus) were anesthetized with an overdose of a mixture of ketamine hydrochloride (Ketaset, 100 $\mathrm{mg} / \mathrm{kg}$, i.m.) and xylazine $(10 \mathrm{mg} / \mathrm{kg}$, i.m.) and perfusion-fixed with $500-$ $700 \mathrm{ml}$ of cold oxygenated Ringer's solution or $0.9 \%$ saline solution followed by $1.2 \mathrm{l}$ of fixative containing $4 \%$ paraformaldehyde and $0.1 \%$ glutaraldehyde in phosphate buffer (PB) $(0.1 \mathrm{M}, \mathrm{pH} 7.4)$. The brains were then removed from the skull, blocked, and post-fixed in the same fixative for $2 \mathrm{hr}$ at $4^{\circ} \mathrm{C}$. After many washes in PBS (0.01 M, pH 7.4), the blocks were cut in $60-\mu \mathrm{m}$-thick transverse sections with a vibrating microtome, collected in cold PBS, and treated for $20 \mathrm{~min}$ with sodium borohydride (1\% in PBS). After repeated washes in PBS, the sections including the SNc and VTA were processed for the immunocytochemical localization of different glutamate receptor subunits and tyrosine hydroxylase $(\mathrm{TH})$ or calbindin- $\mathrm{D}_{28 \mathrm{k}}(\mathrm{CABP})$ immunocytochemistry.

\section{Immunocytochemical procedures}

Five series of adjacent sections (5-10 sections/hemisphere) through the rostrocaudal extent of the midbrain dopaminergic cell groups were processed according to the following immunocytochemical procedures: (1) localization of glutamate receptor subunit immunoreactivity at the light microscopic level, (2) localization of glutamate receptor subunit immunoreactivity at the electron microscopic level, (3) localization of TH immunoreactivity, (4) localization of CABP immunoreactivity, and (5) colocalization of glutamate receptor subunits and $\mathrm{TH}$ immunoreactivities.

Localization of glutamate receptor subunits at the light microscopic level. The sections were placed in a cryoprotectant solution (PB, $0.05 \mathrm{M}, \mathrm{pH} 7.4$, containing $25 \%$ sucrose and $10 \%$ glycerol) for $20 \mathrm{~min}$ before being frozen at $-80^{\circ} \mathrm{C}$ for an additional $20 \mathrm{~min}$. Afterward, they were thawed, washed many times in PBS, and preincubated for $1 \mathrm{hr}$ at room temperature with $10 \%$ normal goat serum (NGS) and $1 \%$ bovine serum albumin (BSA) in PBS. They were then incubated $\left(48 \mathrm{hr}\right.$ at $\left.4^{\circ} \mathrm{C}\right)$ in primary antisera solutions (Chemicon International, Temecula, CA) containing $1 \%$ BSA $/ 1 \%$ NGS/PBS. The concentrations of polyclonal rabbit antibodies against AMPA (GluR1, GluR2/3, and GluR4) and NMDA (NMDAR1 and NMDAR2A/B) receptor subunits were 1.0 and $0.5 \mu \mathrm{g} \mathrm{IgG/ml}$, respectively (Chemicon International). The preparation and specificity of these antibodies have been described in detail elsewhere (Petralia and Wenthold, 1992; Petralia et al., 1994a,b). Subsequently, the sections were rinsed in PBS, incubated for $75 \mathrm{~min}$ with biotinylated goat anti-rabbit IgG (Vector Laboratories, Burlingame, CA), diluted 1:200 in 1\% BSA/1\% NGS/PBS, rinsed again in PBS, and incubated for an additional hour in an avidin-biotin-peroxidase solution (ABC) (Vector Laboratories) diluted at 1:100 in 1\% BSA/PBS. They were then washed in PBS and TRIS buffer $(0.05 \mathrm{M}, \mathrm{pH} 7.6)$ before being placed in a solution containing $0.025 \%$ 3,3'-diaminobenzidine tetrahydrochloride (DAB) (Sigma, St. Louis, MO), $0.01 \mathrm{M}$ imidazole (Fisher Scientific, Nepean, Ontario, Canada), and $0.006 \%$ hydrogen peroxide $\left(\mathrm{H}_{2} \mathrm{O}_{2}\right)$ for $10-15 \mathrm{~min}$. The reaction was stopped by repeated washes in PBS. Some of these sections were mounted onto gelatin-coated slides and dehydrated, and a coverslip was applied with Permount. Another series was processed for electron microscopy, and a third series was used for the colocalization with TH.

Localization of glutamate receptor subunits at the electron microscopic level. The sections prepared for electron microscopy were washed in $\mathrm{PB}$ $(0.1 \mathrm{M}, \mathrm{pH} 7.4)$ before being post-fixed in osmium tetroxide $(1 \%$ solution in PB) for $20 \mathrm{~min}$. They were then washed in PB and dehydrated in a graded series of alcohol and propylene oxide. Uranyl acetate $(1 \%)$ was added to the $70 \%$ ethanol $(30 \mathrm{~min})$ to improve the contrast in the electron microscope. The sections were then embedded in resin (Durcupan, ACM; Fluka, Buchs, Switzerland) on microscope slides and placed in the oven for $48 \mathrm{hr}$ at $60^{\circ} \mathrm{C}$. After examination in the light microscope, regions of interest in the SNc-v were cut out from the slides and glued on the top of resin blocks with cyanoacrylate glue. To ascertain that the blocks did not contain $\mathrm{SNr}$ neurons, they were collected from the medial third of the SNc-v, a region where dopaminergic and nondopaminergic neurons are well segregated (see Fig. $1 A$ ). Ultrathin sections were then cut on a Reichert-Jung Ultracut $\mathrm{E}$ ultramicrotome, collected on Pioloform-coated single-slot copper grids, stained with lead citrate (Reynolds, 1963), and examined with a Phillips EM 300 electron microscope.

Localization of TH immunoreactivity. These sections were preincubated for $1 \mathrm{hr}$ with $1 \%$ normal horse serum (NHS) and 1\% BSA. They were then incubated overnight with mouse monoclonal antibodies against $\mathrm{TH}$ (1:1000, Incstar, Stillwater, MN), followed by a $1 \mathrm{hr}$ incubation with biotinylated horse anti-mouse IgGs and an additional hour with ABC. All of the incubations were carried out at room temperature, and the immunoreactivity was localized with $\mathrm{DAB}$ according to the procedure described above.

Localization of CABP immunoreactivity. This procedure was similar to that described for TH immunostaining, except that monoclonal antibodies raised in mice against CABP (1:2500; Sigma) replaced the TH antibodies.

Colocalization of glutamate receptor subunits and TH. A series of sections immunostained with $\mathrm{DAB}$ for each of the glutamate receptor subunits (see above) were subsequently processed for the colocalization with $\mathrm{TH}$. The protocol for $\mathrm{TH}$ immunostaining was the same as that described above except that the tungstate-stabilized tetramethylbenzidine (TMB) method (Llewellyn-Smith et al., 1993) was used to localize the immunoreactivity. After incubation in the different antibodies and the $\mathrm{ABC}$, the sections were washed three to five times in $\mathrm{PB}(0.1 \mathrm{M}, \mathrm{pH} 6.0)$ before being preincubated in a solution of TMB that was prepared according to the protocol of Llewellyn-Smith et al. (1993). After a $20 \mathrm{~min}$ preincubation, the reaction was initiated by adding glucose oxidase to a final concentration of $0.1 \%$ in a fresh TMB solution. The reaction was terminated after $5-7 \mathrm{~min}$ by extensive washings in $\mathrm{PB}(0.1 \mathrm{M}, \mathrm{pH} 6.0)$. The sections were then mounted onto gelatin-coated slides, air-dried, and dehydrated rapidly, and a coverslip was applied with Permount. A few control sections were incubated in a solution from which the mouse anti-TH antibodies were omitted.

\section{Analysis of material}

Colocalization studies. On the basis of the quality of the double immunostaining, sections from two hemispheres, which have been immunostained for $\mathrm{TH}$ and each of the glutamate receptor subunits, were preselected for determining the proportion of double- versus single-labeled neurons in the SNc and the VTA. These sections were collected from the middle third of the substantia nigra, which is the level where the different groups of midbrain dopaminergic cells are well segregated from nondopaminergic $\mathrm{SNr}$ neurons. At a magnification of $40 \times$, fields in the VTA and the lateral two-thirds of the $\mathrm{SNc}$ were scanned, and every $\mathrm{TH}$ immunoreactive perikarya with a clearly defined cell boundary was categorized as either single-labeled for TH (TMB deposit only) or doublelabeled for TH and GluR (TMB and DAB deposits). Because their boundary could not be defined properly, densely aggregated neurons in the medial third of the SNc were not used for quantitative purposes.

Electron microscopic analysis. At the level of the middle third of the $\mathrm{SNc}$, two blocks were collected from the medial part of the SNc-v in one or two sections immunostained for GluR1, GluR2/3, and NMDAR1 subunits. Fifteen to thirty serial ultrathin sections collected from the surface of each block were cut on an ultramicrotome and examined in the electron microscope. Two or three ultrathin sections from the different hemispheres were then examined to select the cases with a good preservation of ultrastructural features for a more detailed analysis. 


\section{In situ hybridization}

\section{Animals and preparation of tissue}

Four adult male squirrel monkeys (Saimiri sciureus) were used for this part of the study. They were anesthetized deeply with an overdose of pentobarbital $(50 \mathrm{mg} / \mathrm{kg}$, i.v.). The brains were removed quickly and kept frozen at $-70^{\circ} \mathrm{C}$. Coronal sections of the brains $(10 \mu \mathrm{m}$ thick $)$ were cut on a cryostat, collected on gelatin-coated slides, and processed for in situ hybridization histochemistry.

\section{Synthesis of probes}

GluR1 and GluR2 receptor subunit mRNAs were detected by hybridizing sections with oligodeoxynucleotide probes complementary to the rat GluR1 or GluR2 mRNAs. The chosen nucleotidic sequences were identical to those used in other studies and recognized both flip and flop spliced variants of the GluR1 or GluR2 subunits (Sato et al., 1993) (GluR1 = 5'-GTCACTGGTTGTCTGGTCTCGTCCCTCTTCAAACTCTTCGCTGTG-3'; GluR2 = 5'-TTCACTACTTTGTGTTTCTCTTCCATCTTCAAATTCCTCAGTGTG-3'). A total of 20 pmol of each oligodeoxynucleotide was labeled at the $3^{\prime}$ end by terminal transferase with $\left[{ }^{35} \mathrm{~S}\right]$-dATP $(1338 \mathrm{Ci} / \mathrm{mmol}$, Dupont NEN, Wilmington, DE) and purified using a DNA labeling kit (Dupont NEN). The reaction was carried out at $37^{\circ} \mathrm{C}$ for $30 \mathrm{~min}$.

NMDAR1 receptor subunit mRNA was detected by hybridizing sections with a cRNA probe. The $\left[{ }^{35} \mathrm{~S}\right]$ radiolabeled probe was synthesized by transcription in vitro from a cDNA clone encoding for the squirrel monkey NMDAR1 subunit. A random-primed reverse-transcribed cDNA from poly $\left(\mathrm{A}^{+}\right)$RNA of squirrel monkey basal ganglia was used for RT-PCR amplification of NMDAR1 cDNA using a sense primer (TGGAACCACATCATCCTGC) and a reverse primer (GTTCTTGCCGTTGATGAGC). The 351 basepair-long PCR product was ligated in the transcription competent vector pBluescript II SK (Stratagene, La Jolla, CA) for riboprobe synthesis. Transcription of the cRNAs from the cDNAs was performed as described previously (Chesselet et al., 1987) in the presence of $2.5 \mu \mathrm{M}$ of $\left[{ }^{35} \mathrm{~S}\right] \mathrm{UTP}(1000 \mathrm{Ci} / \mathrm{mmol}$, Dupont NEN) and $10 \mu \mathrm{M}$ of unlabeled UTP with ATP, CTP, and GTP in excess. The reaction was carried out for $2 \mathrm{hr}$ at $37^{\circ} \mathrm{C}$, and then the template was digested with DNase I. The labeled cRNAs were purified by phenol/ chloroform extraction and ethanol precipitation.

\section{In situ hybridization procedures}

For each experiment, brain sections at the level of the SN were dried quickly at room temperature under a flow of air and fixed for 5 min by immersion into a solution of $3 \%$ paraformaldehyde in $\mathrm{PB}(1.0 \mathrm{M}, \mathrm{pH} 7.2)$ containing $0.02 \%$ DEPC. The detailed procedure for the in situ hybridization protocol has been described elsewhere (Chesselet et al., 1987; Tremblay et al., 1995). Sections were treated for $10 \mathrm{~min}$ with $0.25 \%$ acetic anhydride and triethanolamine $(0.1 \mathrm{M}, \mathrm{pH} 8.0)$ and for $30 \mathrm{~min}$ with Tris-glycine (1 M, pH 7.0), dehydrated in graded ethanol, and air-dried.

Oligonucleotide probes. Each section was covered with $1-2 \times 10^{6} \mathrm{cpm}$ per $80 \mu \mathrm{l}$ of ${ }^{35} \mathrm{~S}$-labeled DNA probe diluted in hybridization solution containing $40 \%$ formamide, $10 \%$ dextran sulfate, $4 \times$ SSC $(1 \times$ SSC $=$ $0.15 \mathrm{M} \mathrm{NaCl}, 0.015 \mathrm{M}$ sodium citrate), $10 \mathrm{~mm}$ dithiothreitol, $1 \%$ sheared salmon sperm DNA, $1 \%$ yeast tRNA, and $1 \times$ Denhardt's solution containing $1 \%$ of RNase-free BSA. The sections were covered with parafilm, placed in humidified boxes, and incubated overnight in a pulsed-air oven at $37^{\circ} \mathrm{C}$. Posthybridization rinses were in $1 \times \mathrm{SSC}$ for $1 \mathrm{hr}$ at room temperature, $1 \times \mathrm{SSC}$ for $1 \mathrm{hr}$ at $40^{\circ} \mathrm{C}$, and $0.1 \times \mathrm{SSC}$ for $1 \mathrm{hr}$ at $40^{\circ} \mathrm{C}$.

$c R N A$ probe. Each section was covered with $2-4 \mathrm{ng}$ in $30 \mu \mathrm{l}$ of radiolabeled cRNA probe (specific activity: $4 \times 10^{5} \mathrm{cpm} / \mathrm{ng}$ ) diluted in hybridization solution (see above) and incubated for $4 \mathrm{hr}$ in a pulsed-air oven at $50^{\circ} \mathrm{C}$. Sections were then immersed in $50 \%$ formamide and $2 \times$ $\mathrm{SSC}$ at $52^{\circ} \mathrm{C}$ for 5 and $20 \mathrm{~min}$, in RNase A $(100 \mu \mathrm{g} / \mathrm{ml}$; Sigma $)$ and $2 \times$ SSC for $30 \mathrm{~min}$ at $37^{\circ} \mathrm{C}$, and in $50 \%$ formamide and $2 \times$ SSC for $5 \mathrm{~min}$, and left overnight in $2 \times \mathrm{SSC}$ and $0.05 \%$ Triton X-100 at room temperature under mild agitation. Sections were then dehydrated in ethanol, defatted in xylene for $30 \mathrm{~min}$, rinsed in $100 \%$ ethanol, air-dried, and stored in a desiccator until radioautographic processing.

\section{Radioautography}

Sections of the SN labeled with the DNA or cRNA probes were first processed for $\mathrm{x}$-ray film radioautography and then emulsion radioautography. In the first case, sections were juxtaposed to Kodak X-OMAT AR $\mathrm{x}$-ray films and exposed for 2-3 weeks. In the second case, sections were coated with a Kodak NTB3 nuclear emulsion diluted 1:1 with water containing $300 \mathrm{~mm}$ ammonium acetate, air-dried, and stored at $4^{\circ} \mathrm{C}$ in light-tight boxes in the presence of desiccant. After 15-21 or 4-15 d of exposure for film or emulsion radioautography, respectively, the sections were developed in Kodak D-19 for $3.5 \mathrm{~min}$ at $14^{\circ} \mathrm{C}$. Emulsion radioautographs were counterstained lightly with hematoxylin and eosin and mounted with Eukitt mounting media.

\section{Analysis of labeling}

The level of radioautographic labeling for GluR1, GluR2, and NMDAR1 mRNAs was quantified in individual neurons of the SNc-v, SNc-d, and VTA by computerized image analysis (Ultimage). Individual neurons were observed on a microscope at $40 \times$ magnification under bright-field illumination. The number of silver grains in single neurons was calculated on the digitized image and expressed as a number of pixels per neuron. Because the size of the perikarya was quite variable between the $\mathrm{SNc}$ and the VTA, the number of pixels representing the silver grains was expressed per unit area of somata. The perikarya were traced three times, and the average area was used as the final value. In each region investigated, the labeling was measured on 50-100 neurons per monkey from three (for GluR1 subunit) or four (for GluR2 and NMDAR1 subunits) animals. The average level of labeling between SNc-v, SNc-d, and VTA cells was compared with an ANOVA. Post hoc comparisons were performed with the protected least significant difference Fisher's test. Statistical significance was defined as $p<0.05$.

\section{RESULTS}

\section{Subpopulations of midbrain dopaminergic neurons}

The midbrain dopaminergic neurons are subdivided into three groups on the basis of their localization, morphology, and immunoreactivity for CABP (Fig. 1). Neurons in the SNc-v are densely packed, display TH but not CABP immunoreactivity, and extend their dendrites in the dorsoventral plane (Fig. $1 A$ ). Neurons in the SNc-d are more loosely distributed, display immunoreactivity for both TH and CABP, and have dendrites oriented in the mediolateral plane (Fig. $1 B$ ). Finally, neurons in the VTA also display immunoreactivity for both $\mathrm{TH}$ and CABP but are located more medially than neurons in the SNc-d (Fig. 1). To determine the exact location of the neurons immunoreactive for the different glutamate receptor subunits, a series of sections adjacent to those shown in Figures 4-8 were processed for $\mathrm{TH}$ and/or CABP immunostaining. In addition, other sections were processed for the colocalization of $\mathrm{TH}$ and each of the glutamate receptor subunits (Figs. 2, 3).

\section{Colocalization of TH and GluR subunit immunoreactivities}

In sections processed for the localization of the different GluR subunits, all neurons in the SNc-v, SNc-d, and VTA appeared to be immunoreactive (see Figs. 4-7). The only exceptions were those processed to localize the NMDAR2 A/B subunits that were devoid of immunoreactive elements at midbrain level (see Fig. $8 A$ ). To ascertain that all midbrain dopaminergic neurons were indeed immunoreactive for glutamate receptor subunits, we carried out double immunohistochemical staining experiments. The results of this part of the study are shown in Table 1 and Figures 2 and 3. The immunoreactivity for the GluR subunits was localized with the brown and amorphous DAB reaction product, whereas the $\mathrm{TH}$ immunoreactivity was localized with TMB, which results in a filamentous blue-green reaction product (Figs. 2, 3). The majority of neurons in the SNc-v, SNc-d, and VTA contained both DAB and TMB reaction products, which confirms that most of the midbrain dopaminergic neurons display immunoreactivity for the different AMPA (GluR1, GluR2/3, and GluR4) and NMDAR1 glutamate receptor subunits (Figs. $2 A, B, D, E, 3 A, B, D, E$ ). Examination of 2000-3000 TH-immunoreactive neurons at the level of 


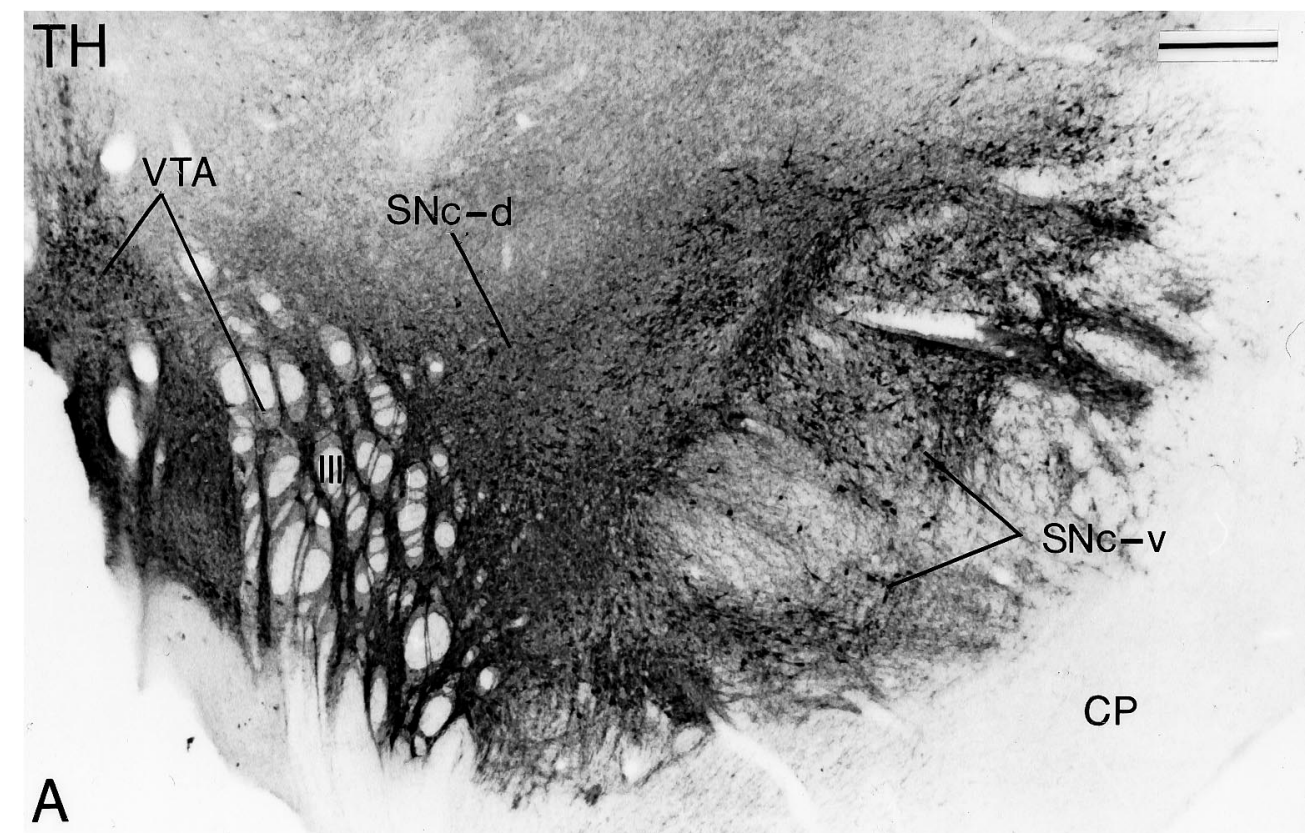

Figure 1. Transverse adjacent sections at the level of the middle one-third of the substantia nigra processed for $T H(A)$ or $C A B P(B)$ immunostaining to illustrate the localization and chemical characteristics of the three midbrain dopaminergic cell groups. The neurons in the ventral tier of the SNc $(S N c-v)$ are densely aggregated, extend their dendrites in the dorsoventral plane, and display $\mathrm{TH}$ but not CABP immunoreactivity. The neurons in the dorsal tier of the SNc $(S N c-d)$ are distributed more loosely, extend their dendrites mediolaterally, and display both $\mathrm{TH}$ and CABP immunoreactivity. The neurons in the VTA are located along the midline and among the roots of the oculomotor nerve $(I I I)$ and are immunoreactive for $\mathrm{TH}$ and $\mathrm{CABP}$. $C P$, Cerebral peduncle. Scale bar (shown in A): $0.5 \mathrm{~mm}$.

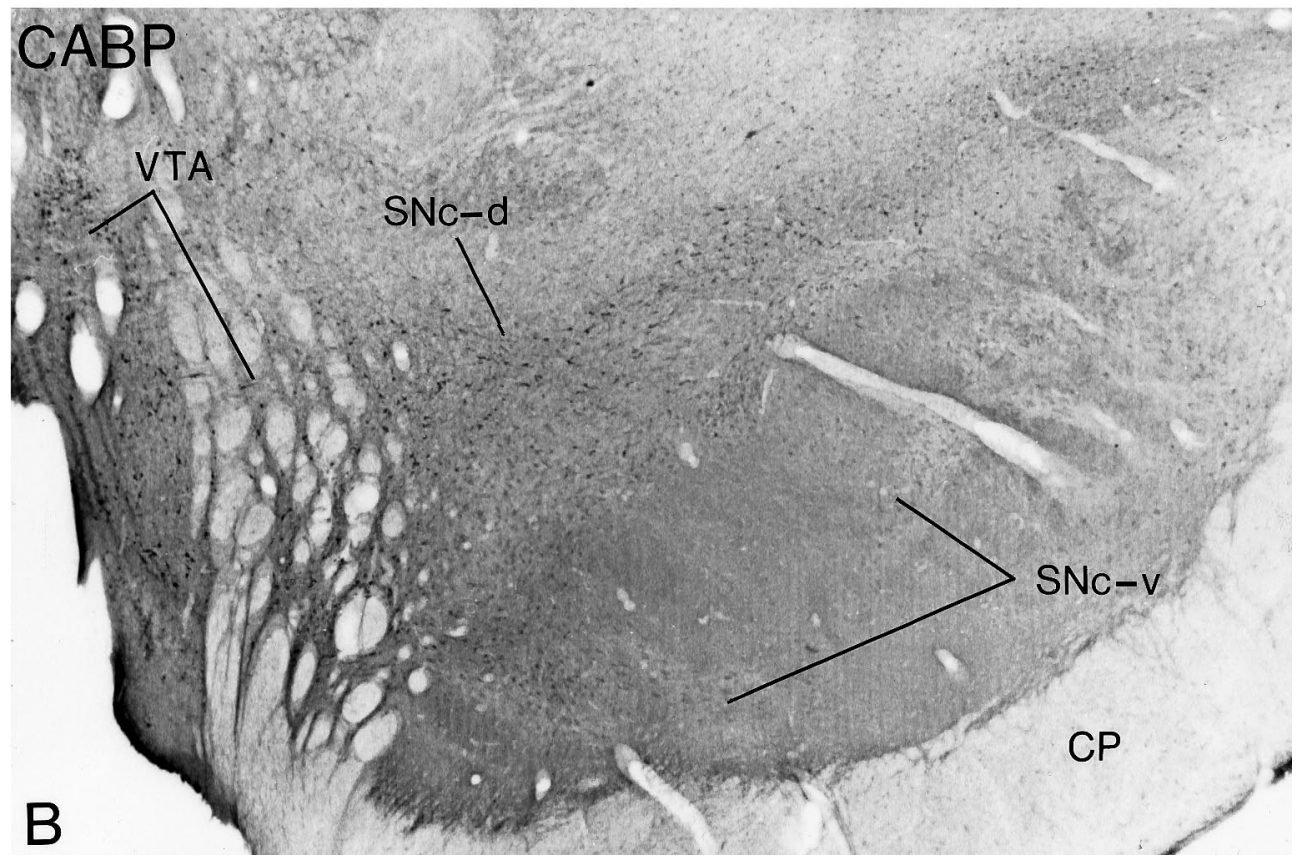

the middle third of the SNc-v and the VTA in two hemispheres revealed that $>98 \%$ of those neurons display immunoreactivity for glutamate receptor subunits (Table 1; Fig. 2C). Because the proportion of double-labeled neurons was not significantly different between the two hemispheres, data obtained in both cases were pooled (Table 1). In contrast to the midbrain dopaminergic cell groups, neurons in the substantia nigra pars reticulata $(\mathrm{SNr})$ were strongly immunoreactive for the different GluR subunits but devoid of TMB reaction product (Fig. $3 C$ ). This indicates the specificity of the double immunostaining; i.e., the TMB reaction product in DAB-stained cells was not attributable to nonspecific attachment between the two reaction products. Furthermore, control sections that were incubated with solutions in which the $\mathrm{TH}$ antibodies had been omitted and replaced by normal serum were devoid of TMB staining.

Table 1. Number of midbrain dopaminergic neurons immunoreactive for the glutamate receptor subunits

Number of double-labeled neurons (\% total number of TH-IR cells examined)

Glutamate receptor subunits

AMPA GluR1 AMPA GluR2/3 AMPA GluR4 NMDAR1

\footnotetext{
TH-IR, TH-immunoreactive.
}

Number of singlelabeled neurons for TH (\% total number of TH-IR cells examined)

\begin{tabular}{lrrrr}
\cline { 1 - 1 } \cline { 5 - 5 } SNc-v & \multicolumn{1}{c}{ VTA } & & \multicolumn{1}{l}{ SNc-v } & \multicolumn{1}{l}{ VTA } \\
\hline $2337(98.9)$ & $1168(98.5)$ & & $27(1.1)$ & $18(1.5)$ \\
$1865(99.5)$ & $933(98.9)$ & & $10(0.5)$ & $10(1.1)$ \\
$1343(99.4)$ & $671(99.0)$ & & $8(0.6)$ & $7(1.0)$ \\
$2211(99.6)$ & $1105(98.9)$ & & $10(0.4)$ & $12(1.1)$
\end{tabular}



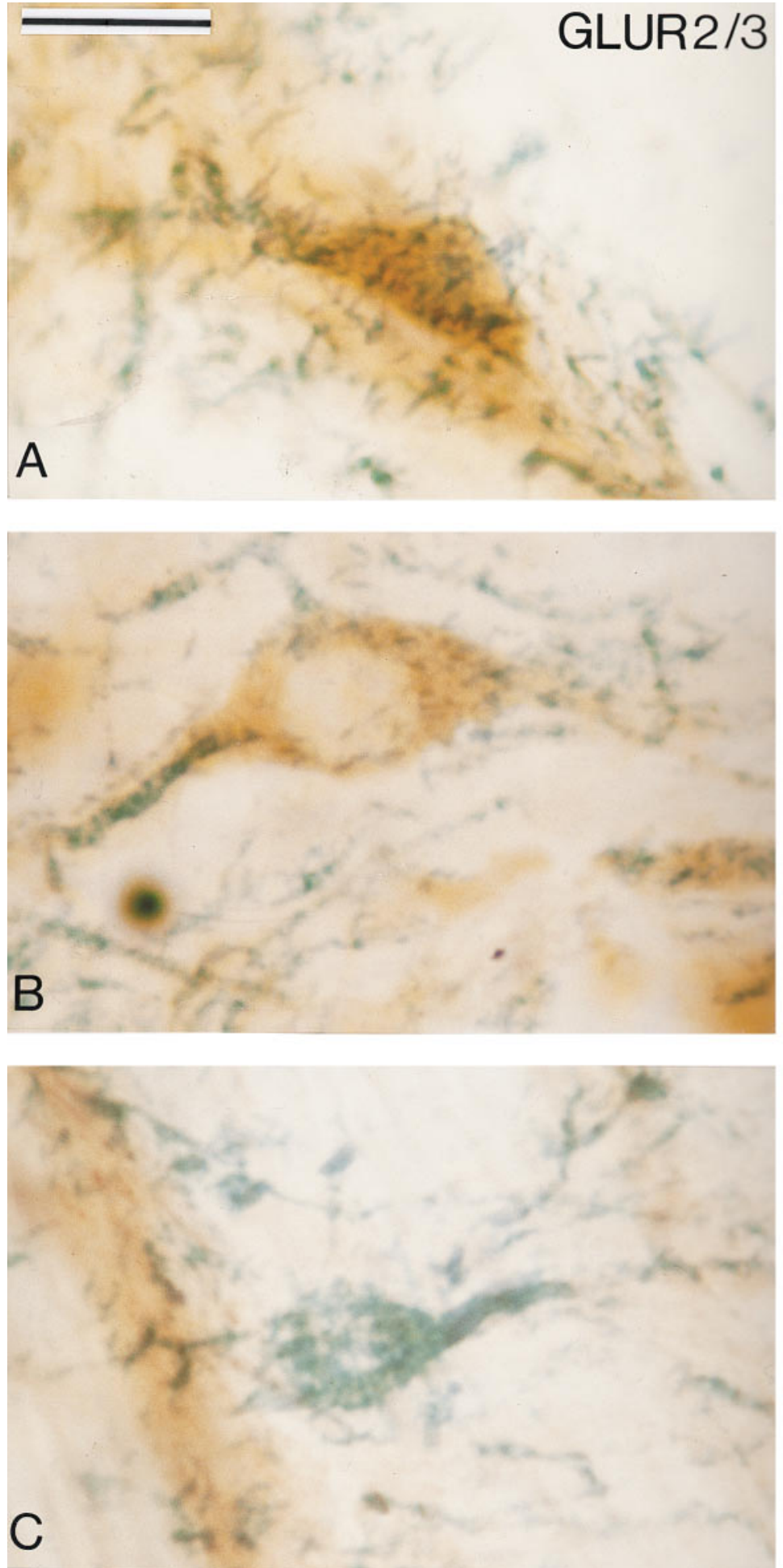
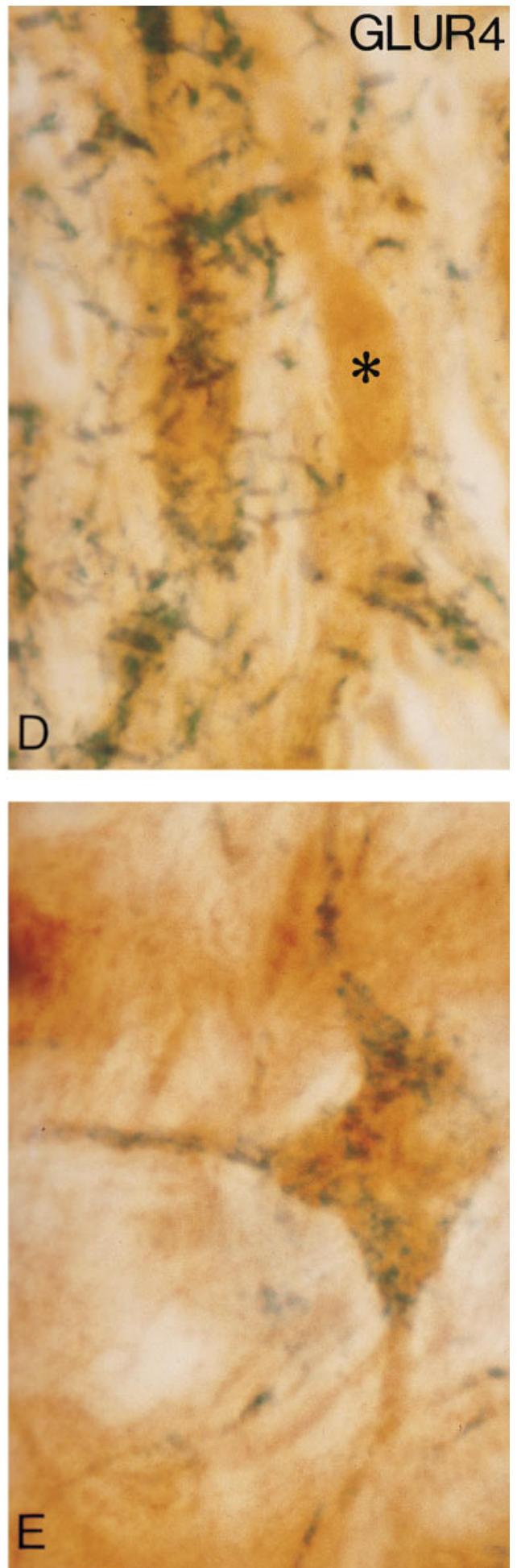

Figure 2. Examples of midbrain dopaminergic neurons processed for the colocalization of AMPA GluR2/3 $(A-C)$ or GluR4 $(D, E)$ subunit and TH immunoreactivities. The glutamate receptor subunits were localized with DAB (brown amorphous reaction product), and TH was revealed with TMB (blue-green filamentous reaction product). $A$ and $B$ show double-labeled neurons in the VTA $(A)$ and the SNc-v $(B)$, whereas $C$ illustrates one of the rare TH-immunoreactive neurons that did not display GluR2/3 immunoreactivity in the VTA. $D$ and $E$ depict double-labeled neurons for GluR4 and TH in the VTA $(D)$ and the SNc $(E)$. The asterisk in $D$ indicates a neuron that is immunoreactive for GluR4 but not for TH in the VTA. Scale bar (shown in $A$ ): $25 \mu \mathrm{m}$.

\section{Pattern of GluR subunit immunostaining AMPA receptor subunits}

The distribution of immunoreactivity for the different AMPA receptor subunits (GluR1, GluR2/3, and GluR4) at midbrain level is shown in Figures 4-6. Overall, the pattern of immunostaining was quite similar for the different subunits. In the three groups of midbrain dopaminergic neurons, the immunoreactivity was confined mainly to perikarya and dendritic processes which, in the 

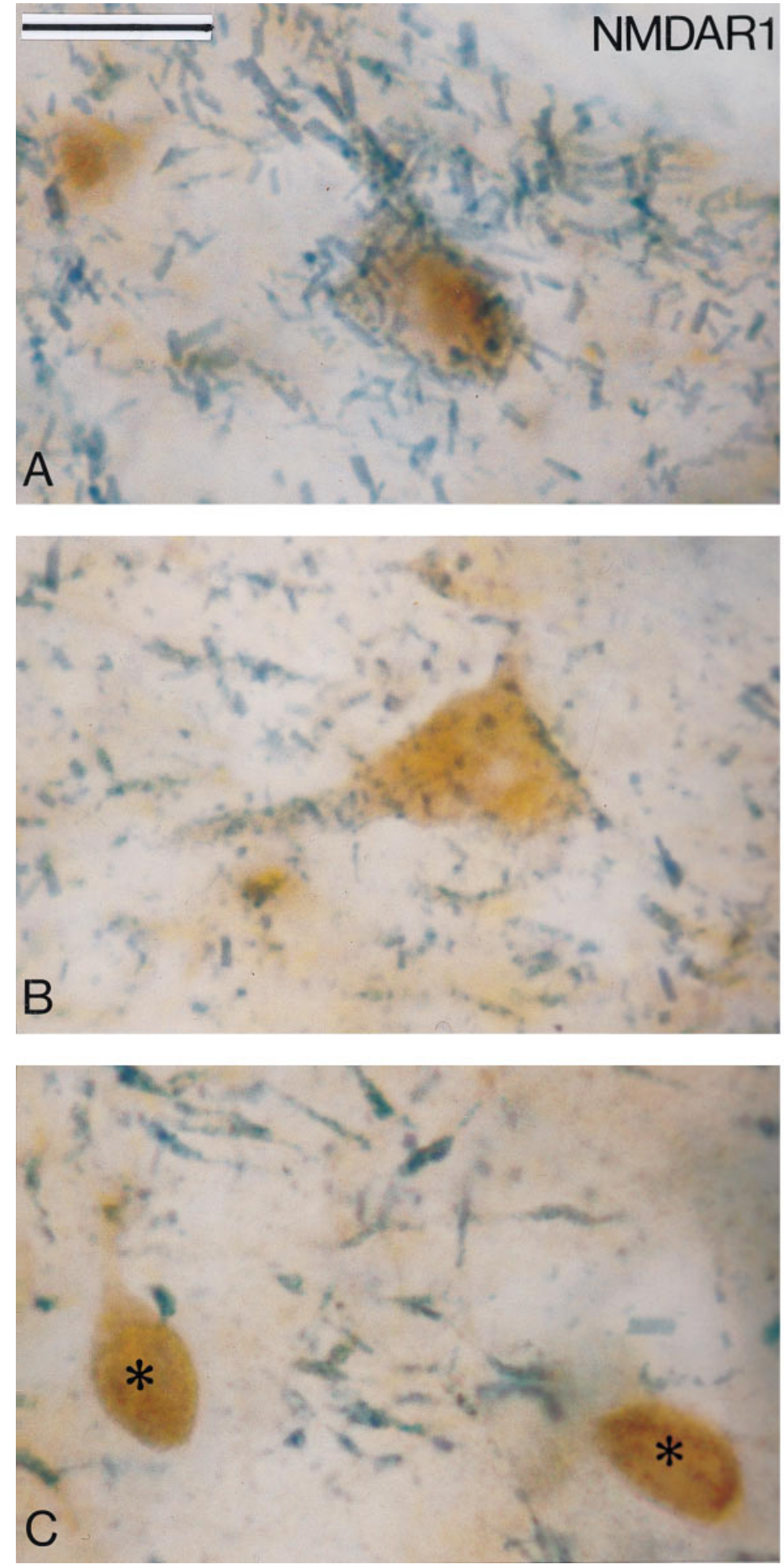
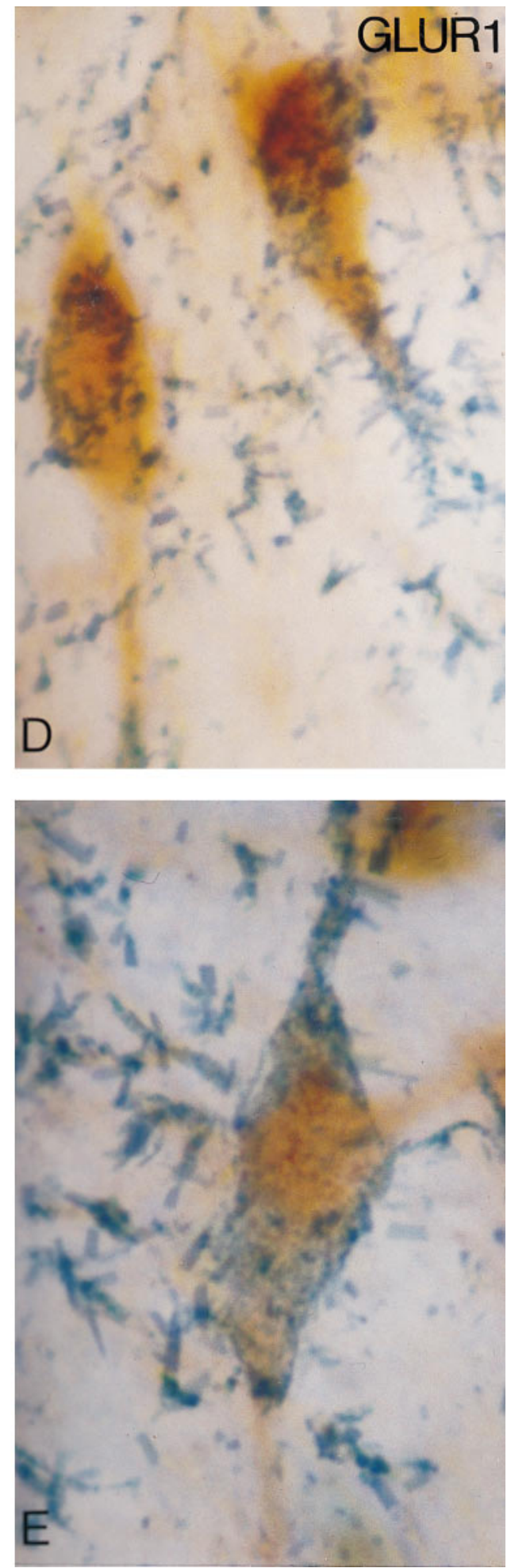

Figure 3. Examples of midbrain dopaminergic neurons processed for the colocalization of NMDAR1 $(A-C)$ or AMPA GluR1 $(D, E)$ subunit and TH immunoreactivities. The glutamate receptor subunits were localized with DAB (brown amorphous reaction product), and TH was revealed with TMB (blue-green filamentous reaction product). $A$ and $B$ show double-labeled neurons for NMDAR1 subunit and TH in the VTA $(A)$ and the SNc-v $(B)$. $C$ shows two neurons in the SNr that are immunoreactive for NMDAR1 (asterisks) but devoid of TH immunostaining. Note the TH-immunoreactive dendrites in the neuropil. $D$ and $E$ depict double-labeled neurons for GluR1 and TH in the VTA $(D)$ and the SNc-v $(E)$. Scale bar (shown in $A$ ): $25 \mu \mathrm{m}$.

SNc-v in particular, were labeled over long distances (Figs. $4 D$, $5 C, 6 C, D)$. In general, the reaction product was homogeneously distributed in immunoreactive structures, except for some neurons in the VTA that displayed strong GluR1 and GluR2/3 labeling confined to the internal surface of the plasma membrane (Figs. $4 B, C, 5 B$ ). A feature common to the three animals used for this part of the study was that the overall intensity of the DAB reaction product associated with GluR1 and GluR2/3 immunore- 

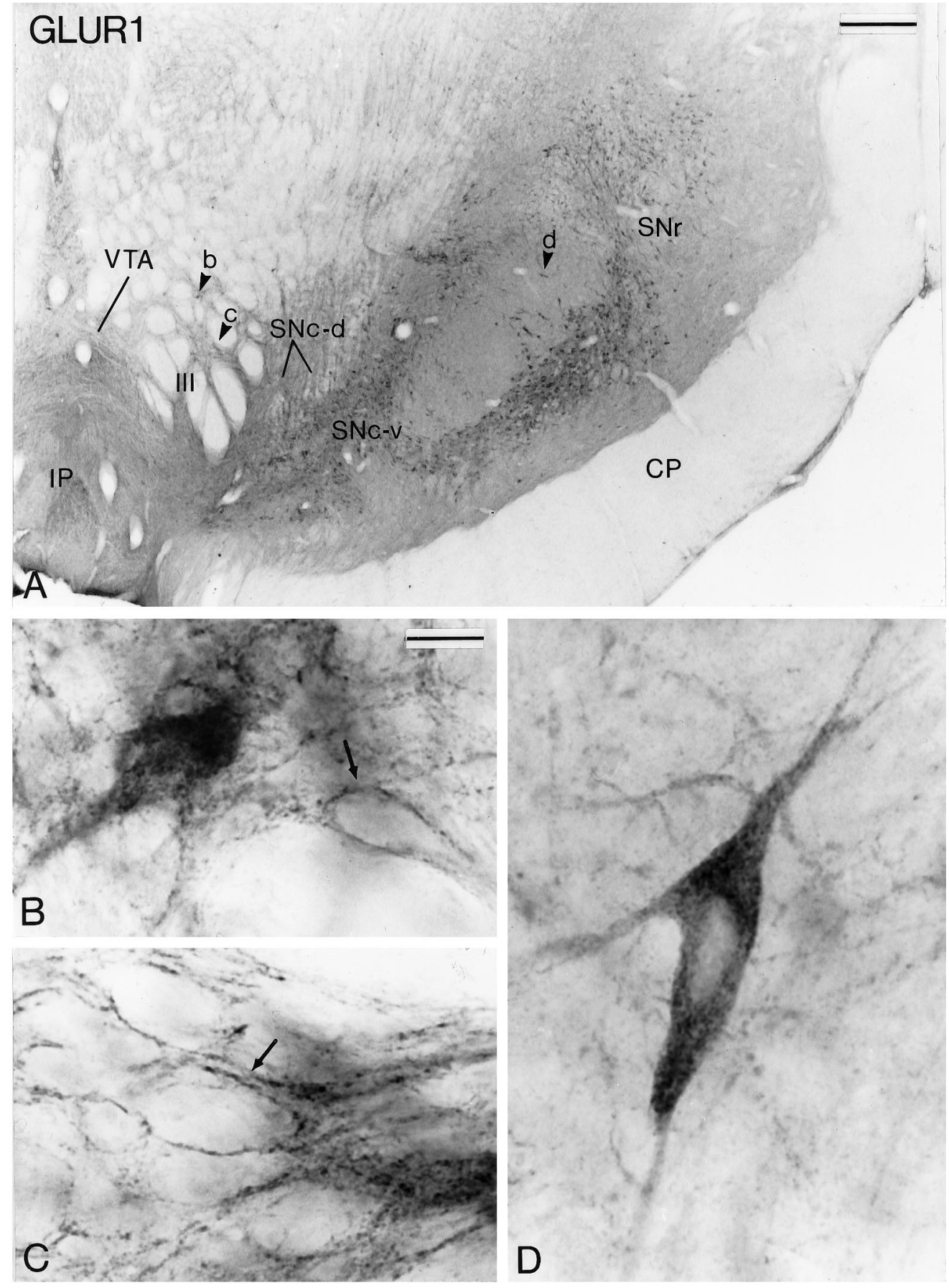

Figure 4. AMPA GluR1 subunit immunoreactivity in midbrain dopaminergic neurons. $A$ shows a low-power view of a transverse section taken at the level of the middle one-third of the substantia nigra. The arrowheads ( $b, c$, d) indicate regions that are shown at higher magnification in $B-D$. $B$ and $C$ show higher-power views of immunoreactive neurons in the VTA. Some neurons are filled homogeneously with the reaction product, whereas others display a dense labeling of the plasma membrane (arrows in $B$ and $C$ ). $D$ depicts a large immunoreactive neuron in the SNc-v. $C P$, Cerebral peduncle; $I P$, interpeduncular nucleus; $S N r$, substantia nigra pars reticulata; $I I I$, roots of the oculomotor nerve. Scale bars: $A, 0.5$ $\mathrm{mm} ; B-D$ (shown in $B), 20 \mu \mathrm{m}$. activity was higher in SNc-v than in SNc-d and VTA neurons (Figs. 4, 5). In contrast, the intensity of GluR4 immunoreactivity was quite homogeneous among the three groups of midbrain dopaminergic neurons (Fig. 6).

\section{NMDA receptor subunits}

The distribution of NMDAR1 and NMDAR2 A/B subunits at midbrain level is shown in Figures 7 and 8. Overall, the distribution of NMDAR1 subunit was quite similar to that of AMPA GluR1 and GluR2/3; however, the pericellular labeling that characterized some of the immunoreactive perikarya in the VTA was not encountered in the NMDAR1 subunitimmunostained material (Fig. 7). The reaction product was distributed rather homogeneously throughout the cytoplasm of immunoreactive neurons. The intensity of immunostaining, however, was quite variable among subpopulations of VTA and SNc-d neurons, the majority being as strongly labeled as neurons in the SNc-v, whereas a few displayed a much lighter immunostaining (Fig. 7B). The lightly stained neurons did not display any particular morphological features or distribution pattern that differentiated them from the more strongly labeled neurons (Fig. 7B). In contrast to the VTA and the SNc-d, all $\mathrm{SNc}-\mathrm{v}$ neurons displayed the same intensity of immunostaining (Fig. 7A,C).

The different populations of midbrain dopaminergic neurons were not immunoreactive for the NMDAR2 A/B subunits (Fig. 


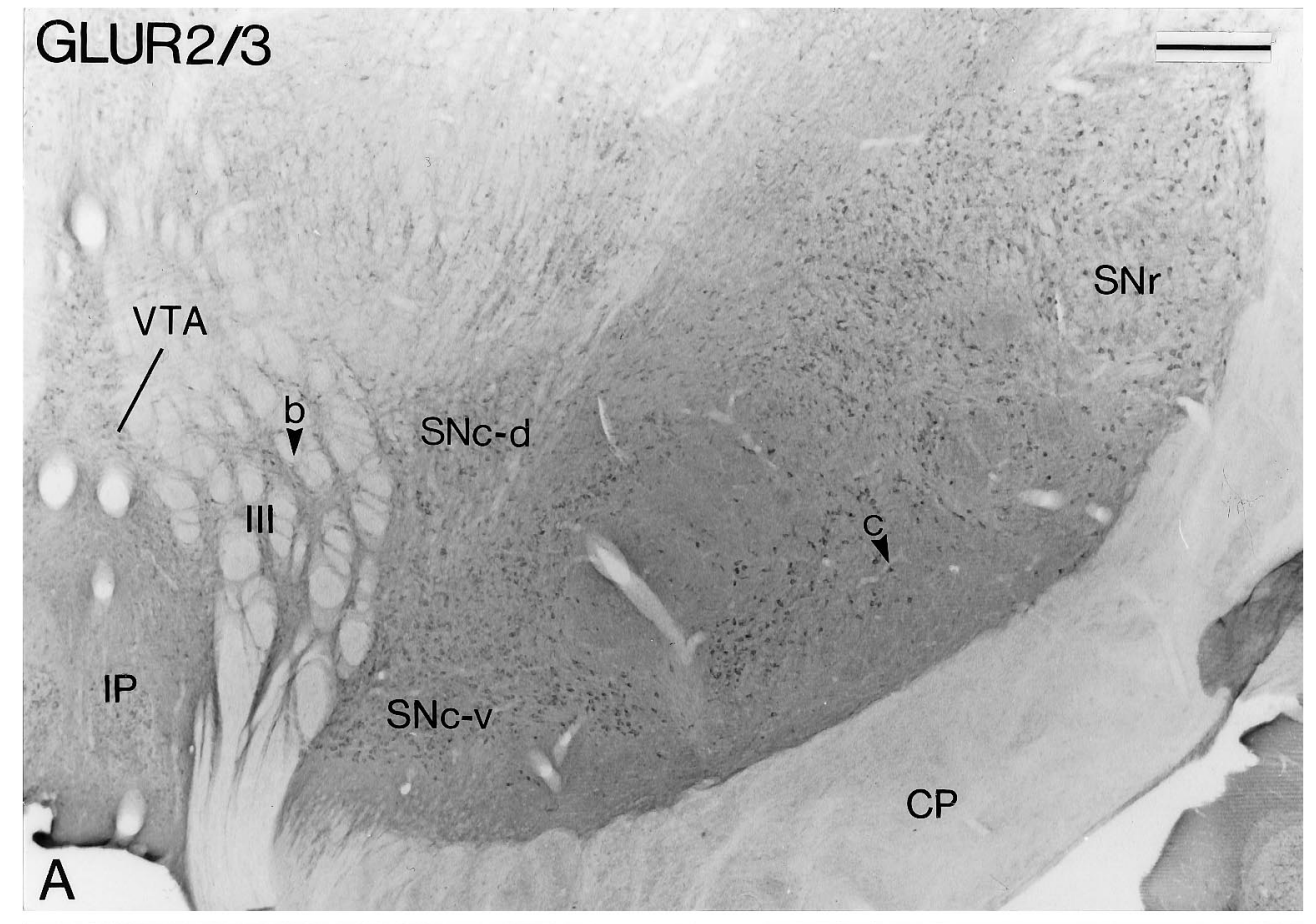

Figure 5. AMPA GluR2/3 subunit immunoreactivity in midbrain dopaminergic neurons. $A$ shows a low-power view of a transverse section taken at the level of the middle one-third of the substantia nigra. The arrowheads in the VTA and the $S N c$ indicate regions shown at higher magnification in $B$ and $C$, respectively. The arrow in $B$ indicates a VTA neuron that displays membranous immunostaining. See Figure 4 for abbreviations. Scale bars: $A, 0.5 \mathrm{~mm}$; $B, C$ (shown in $B$ ), $20 \mu \mathrm{m}$.
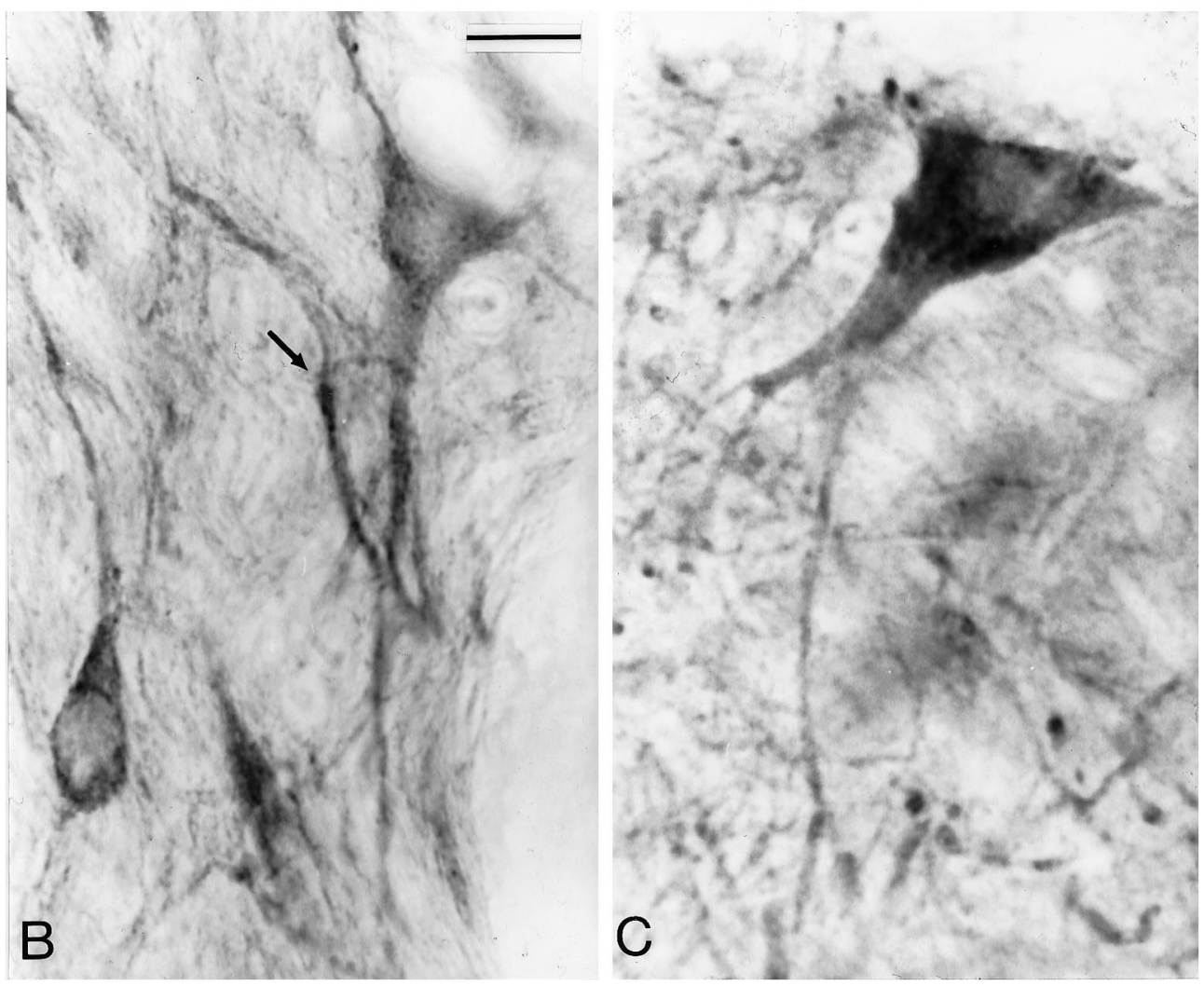

$8 A$ ). A light background staining was observed, but this was considered nonspecific because it was not higher than that displayed in control sections. The fact that neurons in the hippocampus (Fig. 8B) and the cerebral cortex (Fig. 8C) in the same sections were strongly immunoreactive indicates that the lack of immunostaining in midbrain dopaminergic neurons was not attributable to a loss of antigenicity. Rather, it indicates that the NMDAR2 A/B subunits are either not expressed or expressed at a very low level in those neurons.

\section{Glutamate receptor subunit mRNAs in midbrain dopaminergic neurons}

The overall pattern of mRNA labeling for the different glutamate receptor subunits was the same for the four monkeys used in this part of the study. As visualized on x-ray film autoradiographs, the SNc was one of the most strongly labeled structures in sections processed with the rodent DNA probes for AMPA GluR1 and GluR2 subunits and the monkey cRNA probe for 

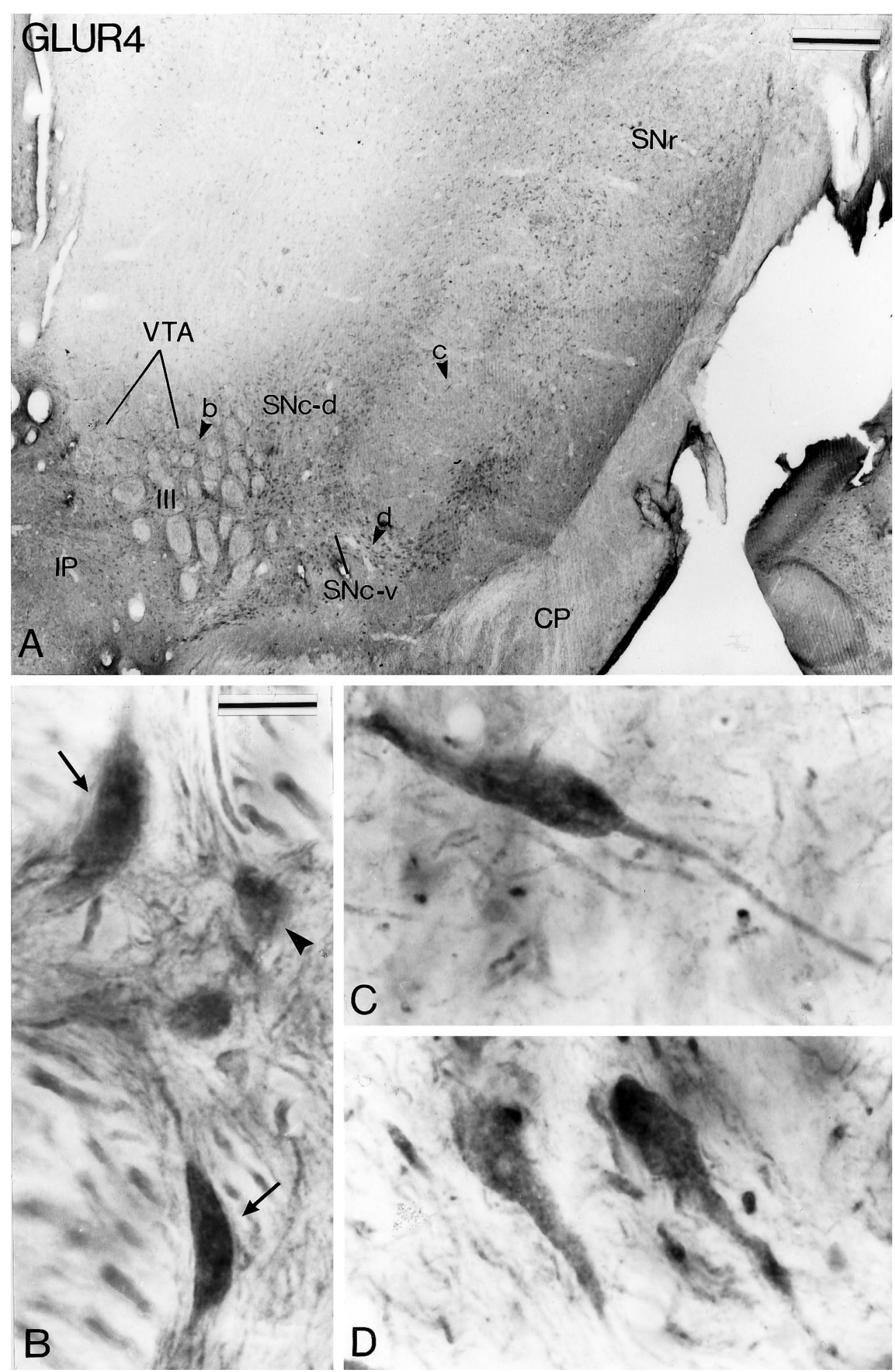

Figure 6. AMPA GluR4 subunit immunoreactivity in midbrain dopaminergic neurons. $A$ shows a low-power view of a transverse section taken at the level of the middle one-third of the substantia nigra. The arrowheads $(b, c, d)$ indicate regions shown at higher magnification in $B-D$. $B$ illustrates different types of GluR4 subunit-positive neurons in the VTA. Some are large and have a fusiform perikaryon (arrows), whereas others are smaller, with a globular shape (arrowhead). $C$ and $D$ show examples of immunoreactive neurons in the SNc-v. See Figure 4 for abbreviations. Scale bars: $A, 0.5$ $\mathrm{mm} ; B-D$ (shown in $B$ ), $20 \mu \mathrm{m}$. the NMDAR1 subunit (Fig. 9). The radioautographic labeling for the NMDAR1 subunit (Fig. 9C) was more intense than that produced for the two AMPA receptor subunits (Fig. 9A,B). As shown previously in the rat (Boulter et al., 1990; Keinänen et al., 1990; Standaert et al., 1994), the hippocampus displayed the highest level of labeling for the different subunit mRNAs (Fig. 9). In line with the immunohistochemical data, the VTA was labeled less intensely than the SNc for the different subunit mRNAs (Figs. 9-11). Quantification of labeling in individual neurons demonstrated that the level of mRNAs encoding for the GluR2 and NMDAR1 subunits was significantly lower in SNc-d and VTA than in SNc-v (Figs. 10C-F, 11). Although the level of NMDAR1 subunit mRNAs was higher in SNc-d than in VTA, no significant difference was found between these two regions for the GluR2 subunit (Fig. 11). It is worth noting that a few neurons were completely devoid of NMDAR1 mRNA labeling in the VTA. The intensity of GluR1 subunit mRNA labeling was not significantly different among the three groups 


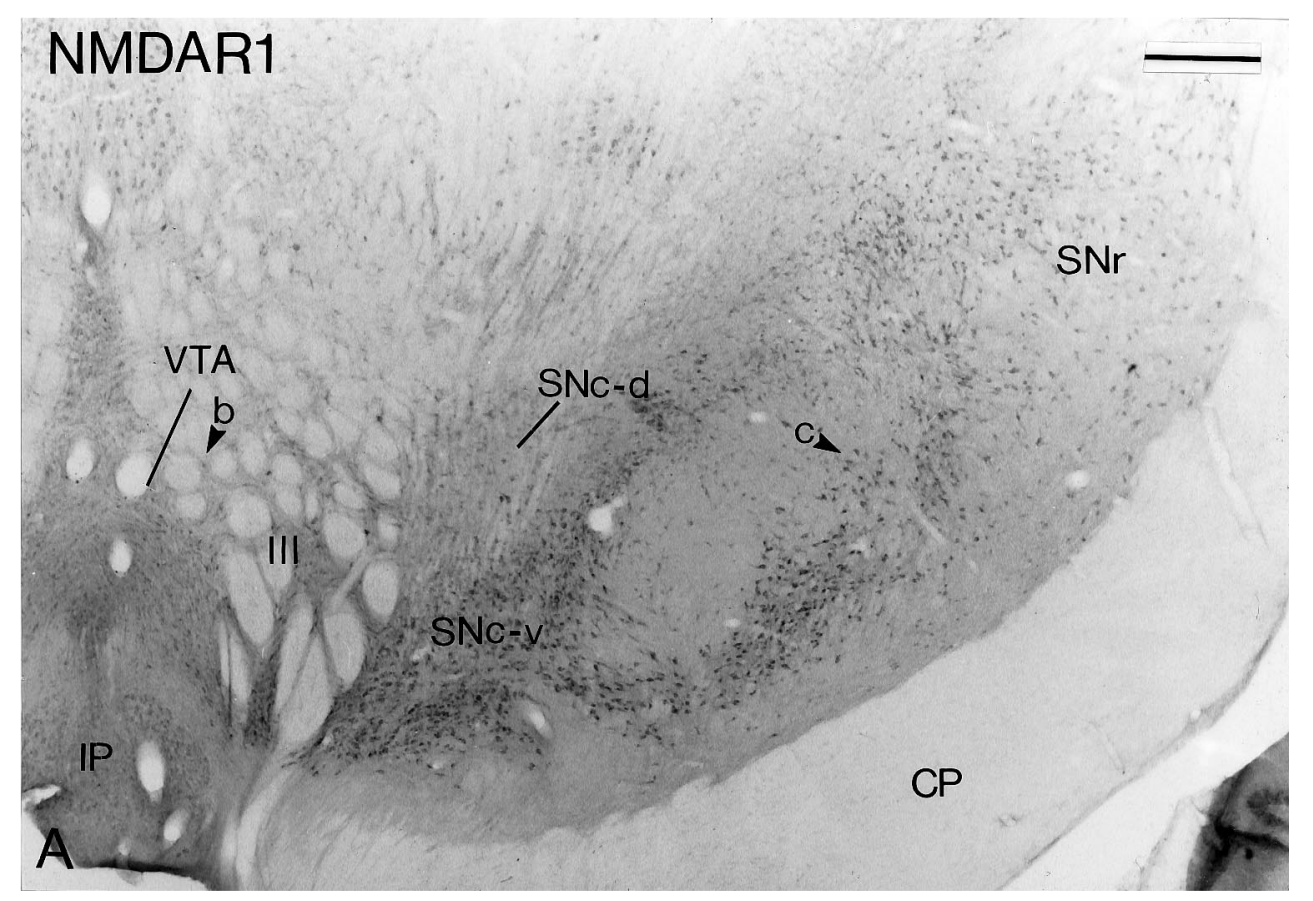

Figure 7. NMDAR1 subunit immunoreactivity in midbrain dopaminergic neurons. $A$ shows a low-power view of a transverse section taken at the level of the middle one-third of the substantia nigra that has been processed for the localization of NMDAR1 subunit immunoreactivity. The arrowheads in the VTA and the $S N c$ indicate regions shown at higher magnification in $B$ and $C$, respectively. Note in $B$ the difference in the intensity of immunostaining between neurons in the VTA. The arrow indicates one of the lightly stained neurons. Scale bars: $A, 0.5 \mathrm{~mm} ; B$, $C$ (shown in $B$ ), $20 \mu \mathrm{m}$.

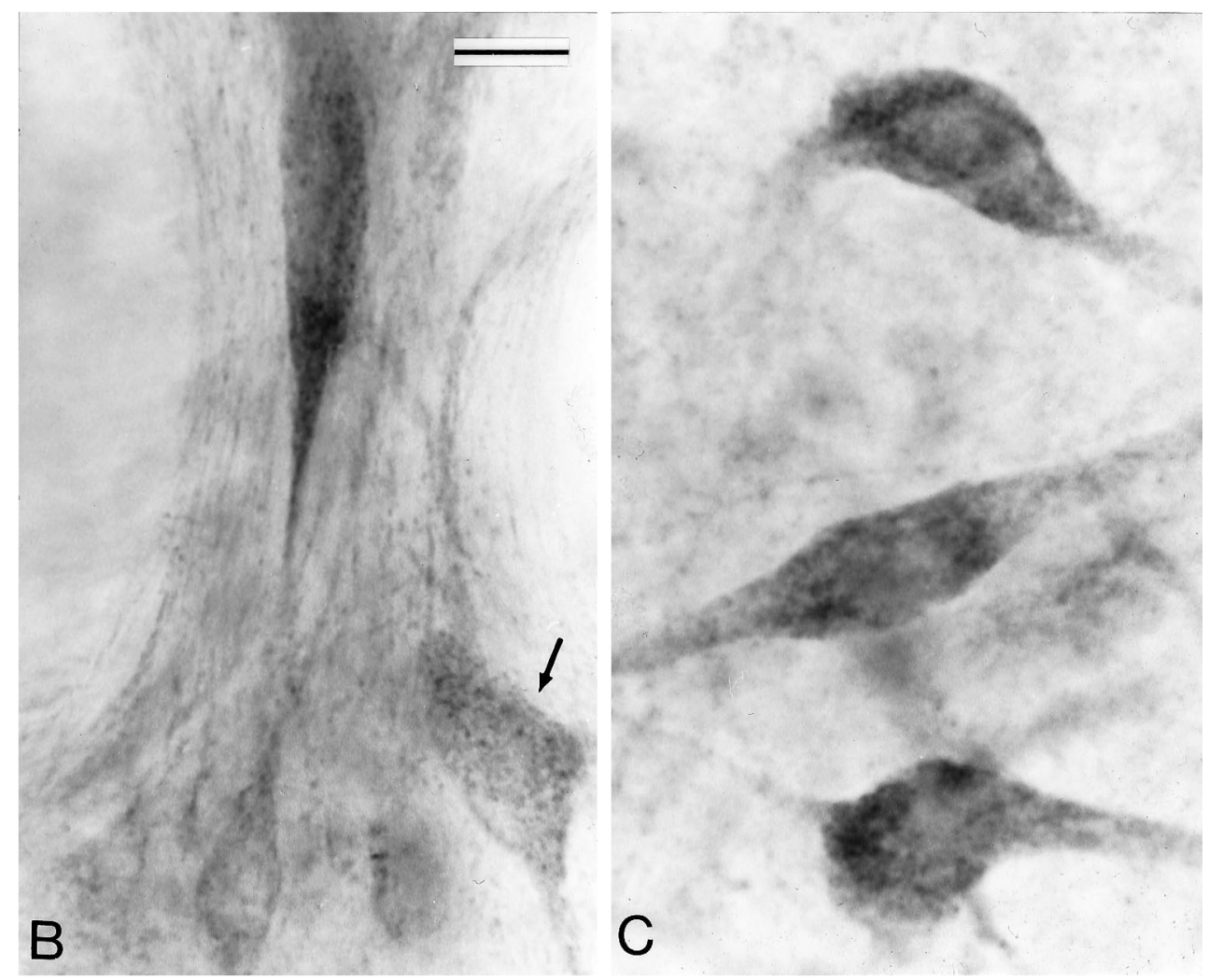

of midbrain dopaminergic neurons (Fig. 11). Glial cells were either devoid of labeling or contained one or two radioautographic grains (Fig. 10).

\section{Subcellular localization of glutamate receptor subunit immunoreactivity in the SNc-v}

On the basis of the preservation of ultrastructural features, two hemispheres of different animals were selected for electron microscopic analysis. Overall, the pattern of subcellular immunostaining for the different subunits was quite similar. In perikarya and dendrites, patches of immunostaining were associated with microtubules, rough endoplasmic reticulum, Golgi apparatus, and nuclear envelope, and occasionally with multivesicular bodies (Fig. 12A). The highest density of immunostaining, however, was associated with the postsynaptic densities of asymmetric synapses established by unlabeled boutons on dendritic shafts (Figs. $12 C-E, 14 A$ ) and spines (Fig. 12B). In many cases, the reaction product was confined almost exclusively to the asymmetric synapses (Figs. 12B,C,E), whereas in others, patches of immunostain- 

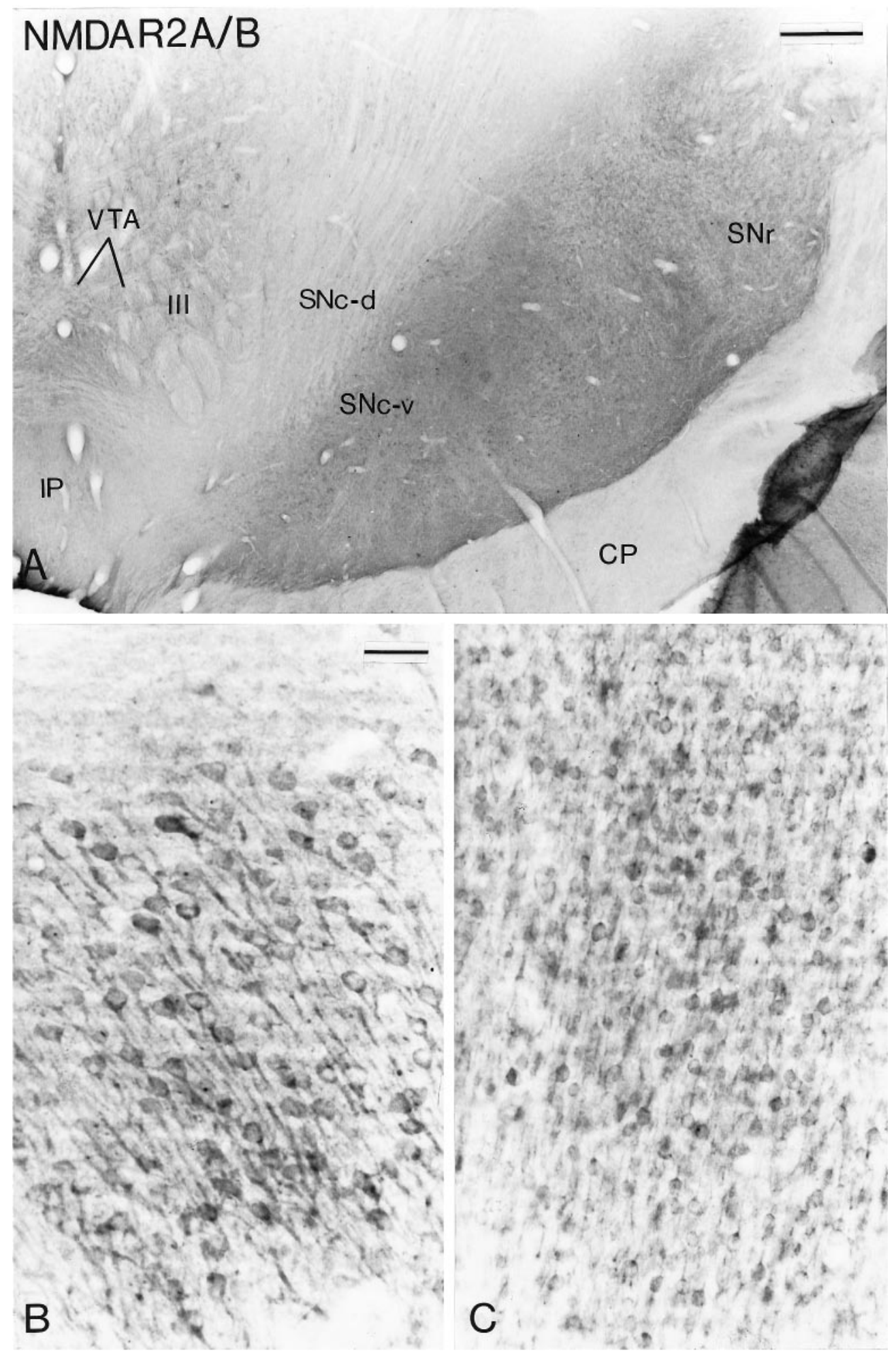

Figure 8. A, Transverse section taken at the level of the middle one-third of the substantia nigra that has been processed for the localization of NMDAR2 A/B subunit immunoreactivity. Note the absence of immunostaining in the $S N c$ and VTA. $B$ and $C$ show immunoreactive neurons in the hippocampus $(B)$ and the cerebral cortex $(C)$ taken in the same section as that shown in $A$. Scale bars: $A$, $0.5 \mathrm{~mm} ; B, C$ (shown in $B$ ), $50 \mu \mathrm{m}$. ing were also found at nonsynaptic sites along the dendrites (Fig. 12A).

Glial cell labeling was found with the different receptor subunit antibodies. Thin immunoreactive glial cell processes often ensheathing unlabeled boutons (Fig. $13 F$ ) were commonly encountered. In contrast, cell bodies of astrocytes were unlabeled. In the cases where the glial cell processes were cut in the longitudinal plane, the labeling was not homogeneous but rather distributed in patches in specific parts of the process (Fig. 13E).
Although it was not encountered frequently, presynaptic labeling was found for GluR1, GluR2/3, and NMDAR1 subunits. The pattern of immunostaining, however, was not the same for the different subunits. The GluR1 subunit immunoreactivity was associated with thin unmyelinated preterminal axonal segments (Fig. 13B,C) and/or terminal boutons (Fig. 13D). In four cases, the preterminal axons displayed strong immunoreactivity, but the terminals they gave rise to were devoid of reaction product (Fig. $13 B, C)$. In fourteen additional cases, part of the preterminal axons 

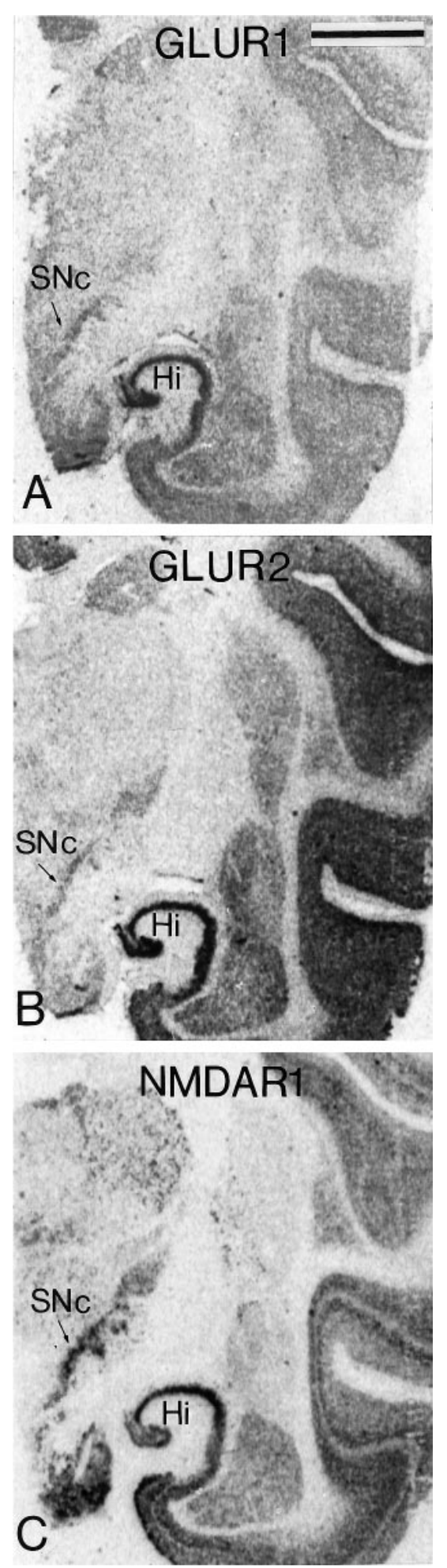

Figure 9. X-ray films from transverse adjacent sections of the substantia nigra processed for in situ hybridization with a ${ }^{35}$ S-labeled cDNA probe for the rat GluR1 $(A)$ and GluR2 $(B)$ mRNAs and a cRNA probe for the monkey NMDAR1 mRNA $(C)$. Note the dense labeling for the different subunits at the level of the $S N c$. Scale bar (shown in $A$ ): $1 \mathrm{~mm}$.

and the terminal boutons forming asymmetric synapses were filled homogeneously with the reaction product (Fig. 13D). In the tissue immunostained for GluR2/3 subunits, four darkly stained immunoreactive terminals packed with large ovoid vesicles (Fig. $12 F$ ) and three thin axonal segments were found to be immunoreactive. Two of the immunoreactive terminals formed symmetric synapses with dendritic shafts (Fig. $12 F$ ). The presynaptic immunostaining for the NMDAR1 subunit was found either in preterminal axons that gave rise to unlabeled boutons with pleomorphic vesicles (Fig. $14 B)(n=5)$ or in terminals that formed asymmetric synapses with dendritic shafts (Fig. $14 C)(n=10)$. Postjunctional dense bodies were associated with the synapses formed by the NMDAR1 subunit-immunoreactive boutons (Fig. 14C).

Thin immunoreactive elements that could be glial cells, thin axons, or small dendrites were encountered frequently in the neuropile for each GluR subunit. These unidentifiable structures were not included in any of the categories of immunoreactive elements described above.

\section{DISCUSSION}

The results of our study provide the first detailed description of the distribution of ionotropic glutamate receptor subunits in midbrain dopaminergic neurons in primates. Three major conclusions can be drawn from our findings. First, the different populations of midbrain dopaminergic neurons are enriched in AMPA (GluR1, GluR2/3, and GluR4) and NMDAR1 receptor subunits, but devoid of NMDAR2A/B subunit. Second, the level of mRNAs encoding for the GluR2 and NMDAR1 subunits is significantly higher in SNc than in VTA dopaminergic neurons. Third, GluR1, GluR2/3, and NMDAR1 immunoreactivity in the SNc is associated with postsynaptic densities of asymmetric synapses, preterminal axons, or terminal boutons and glial cell processes.

\section{Distribution of glutamate receptor subunits in midbrain dopaminergic neurons}

Overall, the pattern of distribution of the AMPA receptor subunits described in our study is consistent with that shown previously in rats by means of in situ hybridization (Sato et al., 1993) and immunocytochemical (Petralia and Wenthold, 1992; Martin et al., 1993) techniques. The only discrepancy between those findings relates to the presence of the GluR4 subunit in midbrain dopaminergic neurons. Although we and others (Petralia and Wenthold, 1992; Sato et al., 1993) showed that almost $100 \%$ of TH-containing neurons in the VTA and SNc express the GluR4 receptor subunit, Martin et al. (1993), using a different antiserum, showed that this subunit was absent in SNc and VTA of the rat. Additional differences in the distribution and cellular localization of GluR4 immunoreactivity were also noticed at the level of the cerebral cortex, hippocampus, and forebrain with the antiserum of Martin et al. (1993). The slight difference in the composition of the synthetic peptides used for making these antibodies is the most likely explanation for this discrepancy (Petralia and Wenthold, 1992; Martin et al., 1993).

Extensive pharmacological and physiological evidence indicates the presence of NMDA receptors in midbrain dopaminergic neurons (Seutin et al., 1990; Overton and Clark, 1992; Chergui et al., 1993; Wang and French, 1993; Zhang et al., 1994; Christoffersen and Meltzer, 1995). In keeping with these observations and previous immunohistochemical (Petralia et al., 1994b) and in situ hybridization studies in rats (Standaert et al., 1994; Laurie et al., 1995; Sato et al., 1995), our findings show that dopaminergic neurons in the SNc and VTA display NMDAR1 subunit immunoreactivity. In contrast, midbrain dopaminergic neurons are devoid of NMDAR2A/B subunit immunoreactivity in the squirrel monkey. These observations are consistent with those made in the rat with the same antibody (Petralia et al., 1994a), although light 


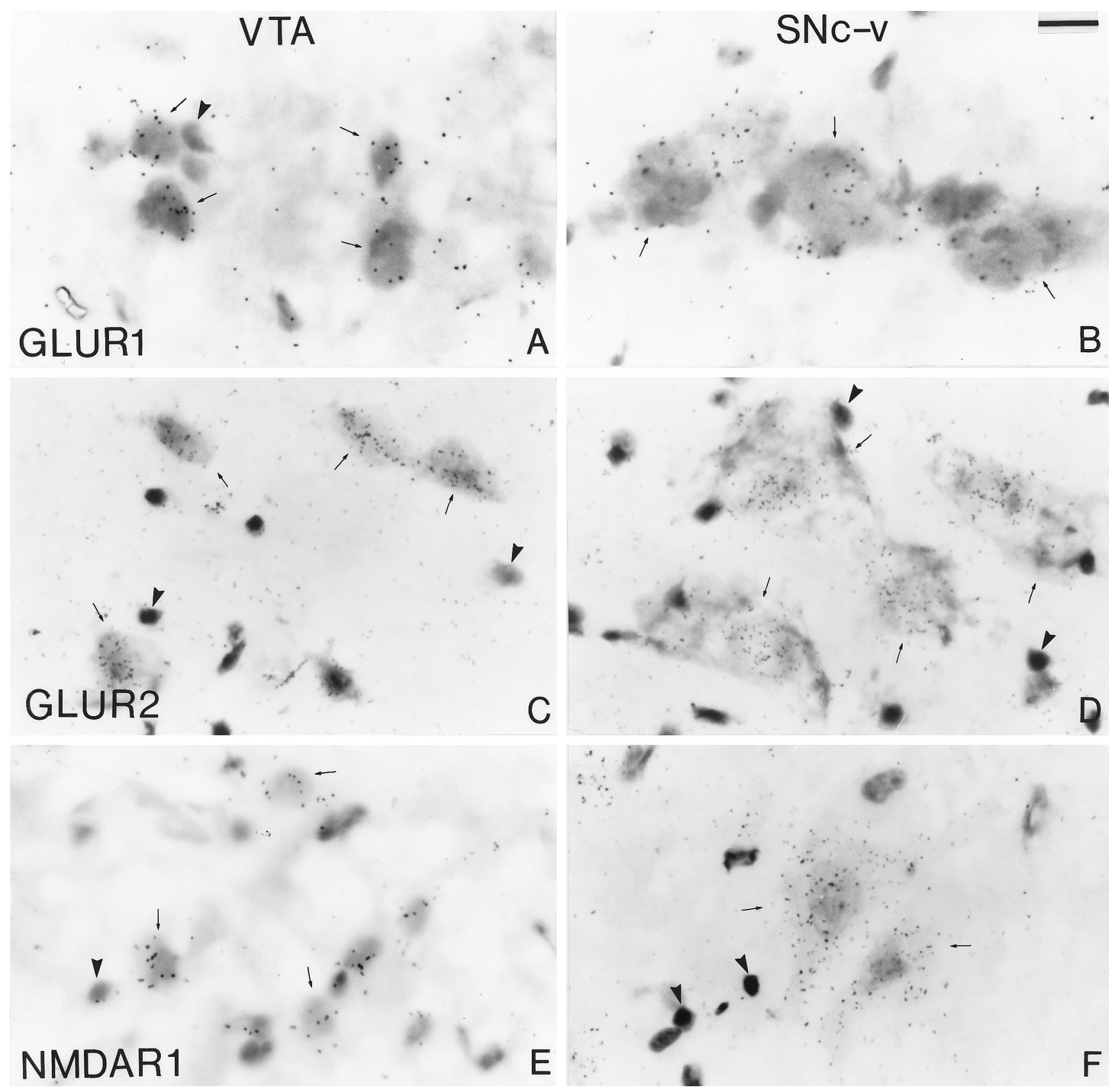

Figure 10. Bright-field photomicrographs of sections processed for in situ hybridization histochemistry with ${ }^{35}$ S-labeled DNA probes for the rat GluR1 $(A, B)$ and $G l u R 2(C, D)$ mRNAs and a cRNA probe for the monkey NMDAR1 mRNA $(E, F)$. Labeled neurons are shown in the VTA $(A, C, E)$ and the $S N c-v(B, D, F)$. The arrows indicate labeled perikarya, whereas the arrowheads point to unlabeled glial cells. Scale bar (shown in $B$ ): $20 \mu \mathrm{m}$.

neuropil immunostaining was found in this study. Similarly, the hybridization signal was found to be very low in the SNc after incubation with probes specific to NMDAR2A and 2B (Standaert et al., 1994). In contrast, the SNc was one of the most intensely labeled structures when hybridized with a probe that recognizes the NMDAR2D subunit (Standaert et al., 1994). Although the subunits of the NMDAR2 family do not form homomeric functional channels in vitro, they markedly potentiate the responses of the NMDA receptor complex to agonists when expressed with NMDAR1 (Monyer et al., 1992; Nakanishi, 1992; Hollman and Heinemann, 1994); however, the specific properties of the different isoforms of NMDAR2 are as yet poorly understood. Future in vitro studies are essential to understand better the functional significance of the relative expression of the different NMDAR1 and NMDAR2 isoforms in midbrain dopaminergic neurons.

\section{Relative abundance of glutamate receptor subunits in} the different groups of midbrain dopaminergic neurons

One major conclusion of our study is that the level of mRNA encoding for the NMDAR1 and GluR2 subunits is significantly higher in SNc than in VTA neurons. Moreover, our findings also show that in the SNc, neurons in the ventral tier have a higher level of NMDAR1 mRNA labeling than neurons in the dorsal tier. This is an important finding, because the relative abundance of subunit mRNAs may account for different functional properties, such as $\mathrm{Ca}^{2+}$ permeability, gating, and desensitization of the native receptor 


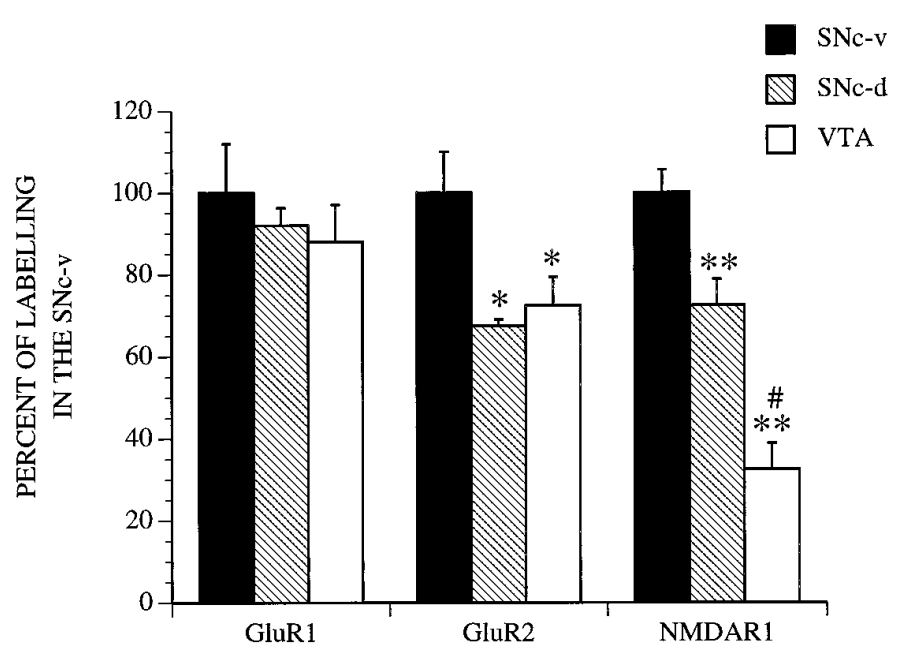

GLUTAMATE RECEPTOR SUBUNITS

Figure 11. Level of radioautographic labeling for different glutamate receptor subunits (GluR1, GluR2, NMDAR1) in the three groups of midbrain dopaminergic neurons $(S N c-v, S N c-d, V T A)$. The values represent the average intensity of labeling measured over individual neurons by computerized image analysis on sections (middle one-third of $\mathrm{SNc}$ ) processed for emulsion autoradiography. The data (mean \pm SEM), which are expressed as a percentage of the labeling in the SNc-v, were obtained from 50-100 neurons per region from four animals for the measurements of GluR2 and NMDAR1 subunits and from three animals for the measurement of GluR1 subunit. No significant difference in labeling was found between the animals. *, $p<0.05$; $^{* *}, p<0.001$ compared with the SNc-v; $\#, p<0.001$ compared with the SNc-d (one-way ANOVA).

channels (Burnashev et al., 1992; Hestrin, 1993; Trussell et al., 1994; Geiger et al., 1995). Because of the lack of attention paid to the VTA in most of the previous studies (Petralia and Wenthold, 1992; Martin et al., 1993; Petralia et al., 1994b; Standaert et al., 1994; Laurie et al., 1995), our findings are difficult to compare with those obtained in rodents. An exception was the recent study of Sato et al. (1995) showing that both NMDAR1 and NMDARgbs (glutamate-binding protein) mRNA expression is much higher in the SNc than in the VTA of the rat (Sato et al., 1995).

Surprisingly, the differential levels of NMDAR1 and GluR2 subunit mRNAs reported in our study are inversely correlated with the density of glutamatergic terminals in contact with $\mathrm{SNc}$ and VTA neurons. Indeed, we showed recently that $>70 \%$ of the axodendritic synapses involve glutamate-enriched terminals in the VTA, whereas $<40 \%$ of the boutons in contact with dendrites in the SNc-v are enriched in glutamate (Smith et al., 1996). A better knowledge of the source, the relative distribution, and the type of receptors activated by glutamatergic afferents in contact with midbrain dopaminergic neurons is essential to understand the significance of these observations. The glutamatergic inputs to SNc and VTA arise from four major sources: the cerebral cortex, the subthalamic nucleus, the pedunculopontine nucleus, and the amygdala. Apart from the amygdaloid inputs, which appear to be restricted largely to the lateral part of the SNc (Gonzales and Chesselet, 1990), the other glutamatergic afferents seem to contribute equally to the innervation of both groups of midbrain dopaminergic neurons (Kornhuber et al., 1984; Groenewegen and Berendse, 1990; Smith et al., 1990; Sesack and Pickel, 1992; Naito and Kita, 1994; Charara et al., 1996). The NMDA receptors were found to mediate the excitatory effects of subthalamic (Chergui et al., 1994, Rosales et al., 1994) and possibly cortical (Gariano and
Groves, 1988; Svensson and Tung, 1989; Tong et al., 1996) afferents, whereas inputs from the pedunculopontine nucleus act preferentially on non-NMDA receptors (Scarnati et al., 1986, Di Loreto et al., 1992). Although these pharmacological and electrophysiological data contributed significantly to our understanding of the effects generated by glutamatergic afferents in dopaminergic neurons, the analysis must now be carried out at a higher level of resolution to elucidate the localization and subunit composition of the glutamate receptors at the synaptic level. One way to reach this objective is to combine the identification of the presynaptic terminals by axonal tracing with the subcellular localization of glutamate receptor subunit immunoreactivity at the electron microscopic level. In the present study, we used the immunoperoxidase labeling to study the subcellular localization of the AMPA and NMDA receptor subunits in SNc-v. As expected, dense reaction product was found to be associated with axo-dendritic asymmetric synapses. In most of the cases in which immunoreactive dendrites received an asymmetric synaptic contact, the postsynaptic densities associated with those synapses were labeled; however, the intensity of labeling was highly variable, extending from a dense aggregate of reaction product to a thin layer of staining. It is noteworthy that the same phenomenon was found in all of the previous peroxidase labeling studies (Martin et al., 1992, 1993; Petralia and Wenthold, 1992; Baude et al., 1994; Petralia et al., 1994a,b). Although the variation in the intensity of staining may be correlated with the relative abundance of antigens, the DAB reaction product is too diffuse to be quantified. Future studies combining the anterograde labeling of glutamate-enriched terminals with postembedding immunogold techniques for the subcellular localization of glutamate receptor subunits (Nusser et al., 1994; Phend et al., 1995) are therefore essential for elucidating this issue. Such an approach can also be used for colocalization studies of glutamate receptor subunits at the synaptic level (Nusser et al., 1994).

\section{Subcellular localization of glutamate receptor subunits Presynaptic labeling}

A small number of preterminal axons and axon terminals were found to be immunoreactive for NMDAR1, GluR1, and GluR2/3 subunits in the SNc-v of the squirrel monkey. In the rat, presynaptic structures immunoreactive for NMDAR1 were found in different brain structures (Aoki et al., 1994; Farb et al., 1995; Gracy and Pickel, 1995). In contrast, presynaptic labeling with GluR1 or GluR2/3 antibodies is much less common (Petralia and Wenthold, 1992; Molnar et al., 1993; Baude et al., 1994, 1995; Farb et al., 1995). In our material, a small number of preterminal axons and terminal boutons involved in asymmetric synapses were found to be immunoreactive for NMDAR1 and GluR1, whereas a few boutons packed with large ovoid vesicles displayed GluR2/3 immunoreactivity. These data imply that glutamate may act on those receptors to modulate presynaptically the release of transmitters in the SNc. Although the existence of presynaptic excitatory amino acid receptors has been suggested in the striatum (Chesselet, 1984; Glowinski et al., 1988; Desce et al., 1992) and hippocampus (Martin et al., 1991), our findings provide the first evidence of presynaptic NMDA and non-NMDA receptors in the SNc of primates. Both NMDAR1 and GluR1-positive boutons displayed the same ultrastructural features, which resembled those of glutamatergic afferents from the subthalamic nucleus (Kita and Kitai, 1987; Bevan et al., 1994, Smith et al., 1994) or the pedunculopontine nucleus (Charara et al., 1996). If such is the case, these afferents could control their own release of glutamate 

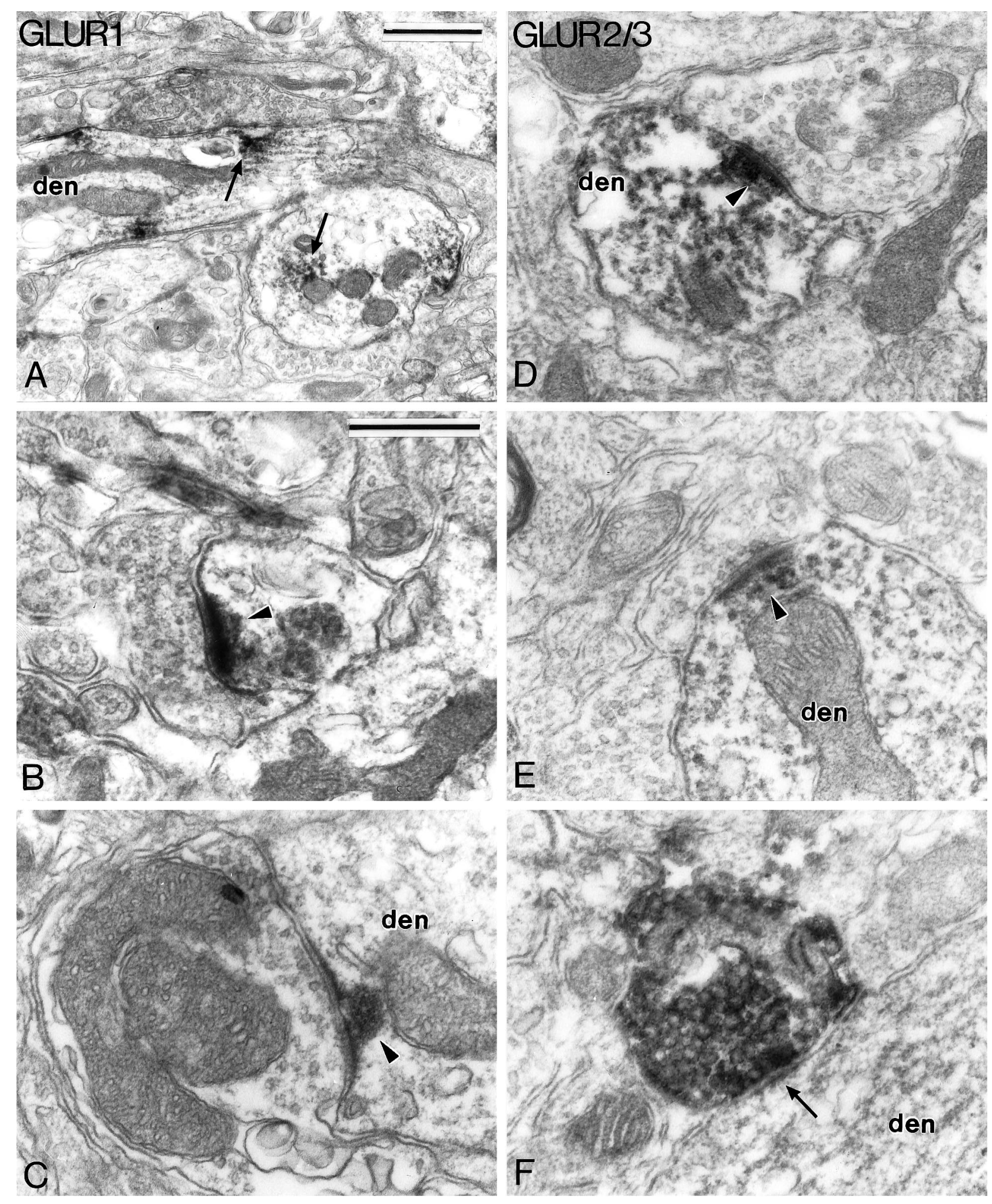

Figure 12. Electron micrographs showing the subcellular localization of AMPA GluR1 $(A-C)$ and GluR2/3 $(D-F)$ subunit immunoreactivities in the SNc-v. $A$ depicts patches of GluR1 subunit immunostaining (arrows) in dendritic shafts (den). $B$ and $C$ illustrate GluR1 subunit immunoreactivity associated with postsynaptic densities of asymmetric synapses (arrowheads) formed with a spine $(B)$ and a large dendritic shaft $(C)$ ). $D$ and $E$ show $G l u R 2 / 3$ subunit immunoreactivity associated with the postsynaptic densities of axo-dendritic asymmetric synapses (arrowheads). $F$ shows one of the rare GluR2/3 subunit-positive boutons encountered in the SNc-v. This bouton is packed with large ovoid vesicles and forms a symmetric synapse (arrow) with a dendrite. Scale bars: $A, 1.0 \mu \mathrm{m} ; B-F$ (shown in $B$ ), $0.5 \mu \mathrm{m}$. 

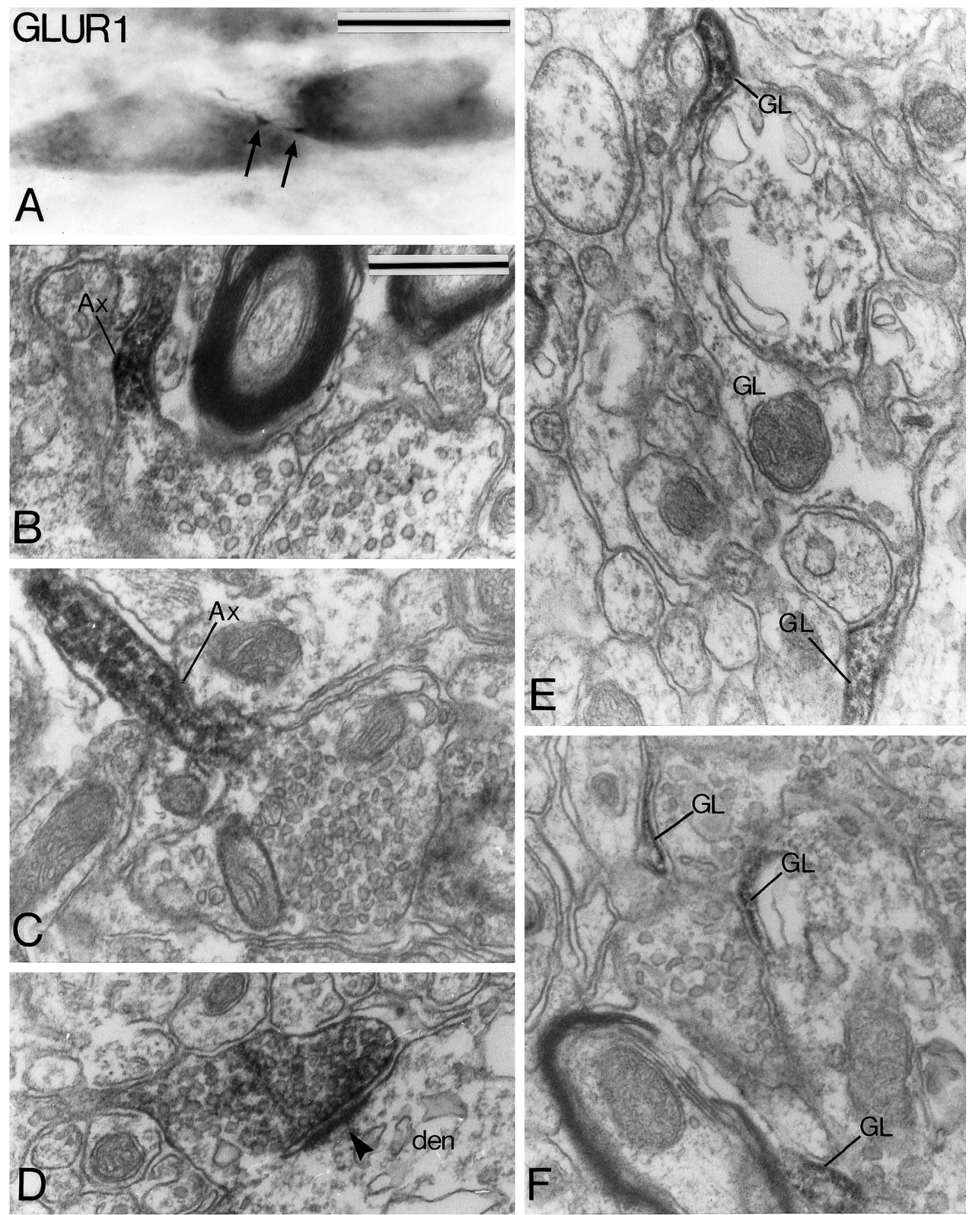

Figure 13. Light $(A)$ and electron micrographs $(B-F)$ showing presynaptic $(A-D)$ and glial cell $(E, F)$ labeling for GluR1 subunit in the SNc-v. $A$ illustrates a thin varicose axon-like process (arrow) between two immunoreactive cell bodies. $B$ and $C$ show immunoreactive preterminal axonal segments $(A x)$ that give rise to nonimmunoreactive terminal boutons. $D$ shows a labeled bouton that forms an asymmetric synapse (arrowhead) with a dendrite (den). $E$ and $F$ illustrate thin labeled glial cell processes. Note in $E$ that the reaction product forms patches in specific parts of the immunoreactive process. Scale bars: $A, 25 \mu \mathrm{m} ; B-F$ (shown in $B$ ), $0.5 \mu \mathrm{m}$.

by activating presynaptic autoreceptors. Presynaptic NMDA receptors may also be involved in the regulation of dopamine release from dendrites in the cat substantia nigra through a tetrodotoxin-resistant process (Gauchy et al., 1994).
The existence of a few GluR2/3-positive terminals that displayed the ultrastructural features of inhibitory terminals suggests that glutamate may also modulate presynaptically the release of GABA in the SNc of primates. 

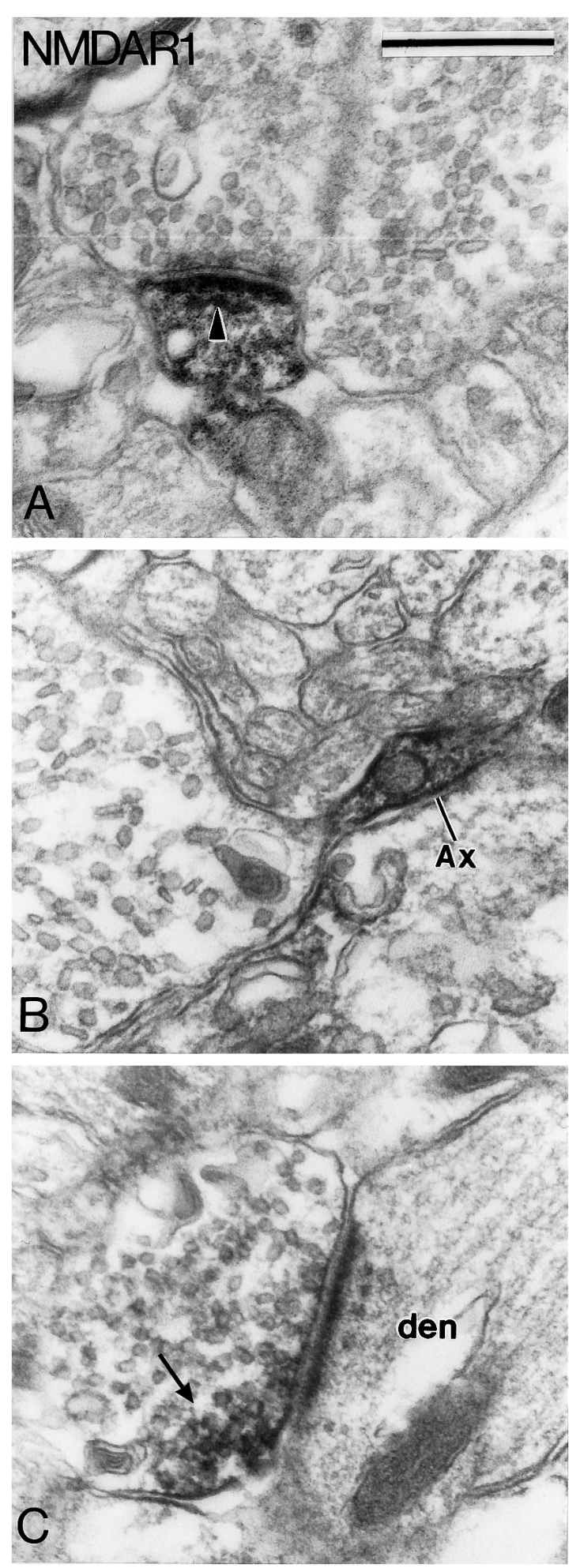

Figure 14. Subcellular localization of NMDAR1 subunit immunoreactivity in the SNc-v. $A$ shows an immunoreactive dendrite that forms an asymmetric synapse (arrowhead) with an unlabeled bouton. $B$ illustrates an immunoreactive preterminal axonal segment that gives rise to a large terminal devoid of immunoreactivity. $C$ depicts an immunoreactive terminal bouton that forms an asymmetric axo-dendritic synapse. Note that the reaction product is confined mainly to a small part of the terminal (arrow). Scale bar (shown in $A$ ): $0.5 \mu \mathrm{m}$.

\section{Glial cell labeling}

Our findings show that glial cell processes contain NMDA and AMPA receptor subunits. Although NMDAR1-positive astrocytes have been found in various brain structures (Aoki et al., 1994; Conti et al., 1994a; Farb et al., 1995; Gracy and Pickel, 1995), glial cell labeling for AMPA receptor subunits is variable (Petralia and Wenthold, 1992; Martin et al., 1993; Baude et al., 1994; Conti et al., 1994b; Spreafico et al., 1994; Farb et al., 1995; Siegel et al., 1995). Glial cell processes in the rat SNc were shown recently to display strong immunoreactivity for the quinolinic acid-synthesizing enzyme 3-hydroxyanthranilic acid oxygenase $\left({ }^{3} \mathrm{HAO}\right)$ (Roberts et al., 1994) or the biosynthetic enzyme of the broad spectrum excitatory amino acid antagonist kynurenic acid (Schwarcz et al., 1992). Quinolinic acid is a brain metabolite, which was found to be a selective NMDA receptor agonist and one of the most powerful excitotoxins in the brain (Stone and Perkins, 1981; Schwarcz and Köhler, 1983). In contrast, kynurenic acid attenuates NMDA-induced excitation of $\mathrm{SNc}$ dopaminergic neurons in the rat (Wu et al., 1994). Glutamate receptors therefore may act as autoreceptors that control the glial cell release of these excitatory amino acid agonists and antagonists in the SNc.

\section{Excitotoxicity and Parkinson's disease}

It is well established that excessive stimulation of glutamate receptors may lead, under certain circumstances, to neuronal death (Choi, 1988, 1992; Beal, 1992a). This phenomenon, called excitotoxicity (Olney et al., 1971), relies mainly on massive influx of $\mathrm{Ca}^{2+}$ through NMDA receptor channels (Rothman and Olney, 1987; Choi, 1988, 1992; Michaels and Rothman, 1990; Beal, 1992a; Blandini et al., 1996). Indirect evidence indicates that excitotoxicity could be involved in the degeneration of midbrain dopaminergic neurons in Parkinson's disease (for review, see Blandini et al., 1996). In keeping with this hypothesis, neurons in the VTA and the SNc-d, which contain the calcium-binding protein calbindin $\mathrm{D}_{28 \mathrm{k}}$, are selectively spared in Parkinson's disease (see introductory remarks). Moreover, our findings in squirrel monkeys show that neurons in the SNc-v display a much higher level of NMDAR1 subunit than the two other groups of midbrain dopaminergic neurons. Therefore, the lack of calcium binding protein combined with the larger density of $\mathrm{Ca}^{2+}$-permeable NMDA channels could make dopaminergic neurons in the SNc-v more sensitive to excitotoxicity than other dopaminergic cell groups in Parkinson's disease.

Numerous observations indicate that a combination of impairment in energy metabolism or oxidative stress and activation of NMDA receptors induces a selective toxicity toward midbrain dopaminergic neurons in the SNc-v (Sonsalla et al., 1989; Turski et al., 1991; Beal, 1992b; Turski and Stephens, 1992; Brouillet and Beal, 1993; Lange et al., 1993; MareySemper et al., 1995; Blandini et al., 1996). An important aspect of this hypothesis is that glutamate levels need not be abnormally high to induce the neuronal degeneration (Blandini et al., 1996). NMDA receptor antagonists therefore should be considered potential candidates for preventing the death of dopaminergic neurons in Parkinson's disease. Because of the wide distribution of NMDA receptors in the brain, however, NMDA receptor antagonists evoke a number of undesirable symptoms, including psychostimulation, impairment of learning and memory, and severely disordered movements (for reviews, see Ossowska, 1994; Starr, 1995a,b). A better knowledge of the sub- 
unit composition of the NMDA receptors associated with glutamatergic afferents on SNc dopaminergic neurons is essential for the use of more specific NMDA antagonists in Parkinson's disease.

\section{REFERENCES}

Aoki C, Venkatesan C, Go C-G, Mong JA, Dawson TM (1994) Cellular and subcellular localization of NMDA-R1 subunit immunoreactivity in the visual cortex of adult and neonatal rats. J Neurosci 14:5202-5222.

Baude A, Molnar E, Latawiec D, McIlhinney RAJ, Somogyi P (1994) Synaptic and nonsynaptic localization of the GluR1 subunit of the AMPA-type excitatory amino acid receptor in the rat cerebellum. J Neurosci 14:2830-2843.

Baude A, Nusser Z, Molnar E, McIlhinney RAJ, Somogyi P (1995) High-resolution immunogold localization of AMPA type glutamate receptor subunits at synaptic and non-synaptic sites in rat hippocampus. Neuroscience 69:1031-1055.

Beal MF (1992a) Mechanisms of excitotoxicity in neurologic diseases. FASEB J 6:3338-3344.

Beal MF (1992b) Does impairment of energy metabolism result in excitotoxic neuronal death in neurodegenerative illnesses? Ann Neurol 31:119-130.

Bevan MD, Bolam JP, Crossman AR (1994) Convergent synaptic input from the neostriatum and the subthalamus onto identified nigrothalamic neurones in the rat. Eur J Neurosci 6:320-334.

Blandini F, Porter RHP, Greenamyre JT (1996) Glutamate and Parkinson's disease. Mol Neurobiol 12:73-94.

Boulter J, Hollmann M, O'Shea-Greendfield A, Hartley M, Deneris E, Maron C, Heinemann S (1990) Molecular cloning and functional expression of glutamate receptor subunit genes. Science 249:1033-1037.

Brouillet E, Beal MF (1993) NMDA antagonists partially protect against MPTP induced neurotoxicity in mice. NeuroReport 4:387-390.

Burnashev N, Monyer H, Seeburg PH, Sakmann B (1992) Divalent ion permeability of AMPA receptor channels is dominated by the edited form of a single subunit. Neuron 8:189-198.

Charara A, Smith Y, Parent A (1996) Glutamatergic inputs from the pedunculopontine nucleus to midbrain dopaminergic neurons in primates: Phaseolus vulgaris-leucoagglutinin anterograde labeling combined with postembedding glutamate and GABA immunohistochemistry. J Comp Neurol 364:254-266.

Charlety PJ, Grenhoff J, Chergui K, De La Chapelle B, Buda M, Svensson $\mathrm{TH}$, Chouvet G (1991) Burst firing of mesencephalic dopamine neurons is inhibited by somatodendritic application of kynurenate. Acta Physiol Scand 142:105-112.

Chergui K, Charléty PJ, Akaoka H, Saunier CF, Brunet J-L, Buda M, Svensson TH, Chouvet G (1993) Tonic activation of NMDA receptors causes spontaneous burst discharge of rat midbrain dopamine neurons in vivo. Eur J Neurosci 5:137-144.

Chergui K, Akaoka H, Charléty PJ, Saunier CF, Buda M, Chouvet G (1994) Subthalamic nucleus modulates burst firing in nigral dopamine neurones via NMDA receptors. NeuroReport 5:1185-1188.

Chesselet M-F (1984) Presynaptic regulation of neurotransmitter release in the brain: facts and hypothesis. Neuroscience 12:347-375.

Chesselet M-F, Weiss LT, Wuenschell C, Tobin AJ, Affolter HU (1987) Comparative distribution of mRNAs for glutamic acid decarboxylase, tyrosine hydroxylase and tachykinins in the basal ganglia: an in situ hybridization study in the rodent brain. J Comp Neurol 262:125-140.

Choi DW (1988) Glutamate neurotoxicity and diseases of the nervous system. Neuron 1:623-634.

Choi DW (1992) Excitotoxic cell death. J Neurobiol 23:1261-1276.

Christoffersen CL, Meltzer LT (1995) Evidence for $N$-methyl-Daspartate and AMPA subtypes of the glutamate receptor on substantia nigra dopamine neurons: possible preferential role for $N$-methyl-Daspartate receptors. Neuroscience 67:373-381.

Conti F, Minelli A, Brecha NC (1994a) Cellular localization and laminar distribution of AMPA glutamate receptor subunits mRNAs and proteins in the rat cerebral cortex. J Comp Neurol 350:241-259.

Conti F, Minelli A, Molnar M, Brecha NC (1994b) Cellular localization and laminar distribution of NMDAR1 mRNA in the rat cerebral cortex. J Comp Neurol 343:554-565.
Desce JM, Godeheu G, Galli T, Artaud F, Chéramy A, Glowinski J (1992) L-glutamate-evoked release of dopamine from synaptosomes of the rat striatum: involvement of AMPA and $N$-methyl-D-aspartate receptors. Neuroscience 47:333-339.

Di Loreto S, Florio T, Scarnati E (1992) Evidence that non-NMDA receptors are involved in the excitatory pathway from the pedunculopontine region to nigrostriatal dopaminergic neurons. Exp Brain Res 89:79-86.

Farb CR, Aoki C, Ledoux JE (1995) Differential localization of NMDA and AMPA receptor subunits in the lateral and basal nuclei of the amygdala: a light and electron microscopic study. J Comp Neurol 362:86-108.

Gariano RF, Groves PM (1988) Burst firing induced in midbrain dopamine neurons by stimulation of the medial prefrontal and anterior cingulate cortices. Brain Res 462:194-198.

Gasic GP, Hollmann M (1992) Molecular neurobiology of glutamate receptors. Annu Rev Physiol 54:507-536.

Gauchy C, Desban M, Glowinski J, Kemel ML (1994) NMDA regulation of dopamine release from proximal and distal dendrites in the cat substantia nigra. Brain Res 635:249-256.

Geiger JRP, Melcher T, Koh D-S, Sakmann B, Seeburg PH, Jonas P, Monyer H (1995) Relative abundance of subunit mRNAs determines gating and $\mathrm{Ca}^{+2}$ permeability of AMPA receptors in principal neurons and interneurons in rat CNS. Neuron 15:193-204.

Glowinski J, Chéramy A, Romo R, Barbeito L (1988) Presynaptic regulation of dopaminergic transmission in the striatum. Cell Mol Neurobiol 8:7-17.

Gonzales C, Chesselet M-F (1990) Amygdalonigral pathway: an anterograde study in the rat with Phaseolus vulgaris-leucoagglutinin (PHA-L). J Comp Neurol 297:182-200.

Grace AA, Bunney BS (1984) The control of firing pattern in nigral dopamine neurons: burst firing. J Neurosci 4:2877-2890.

Gracy KN, Pickel VM (1995) Comparative ultrastructural localization of the NMDAR1 glutamate receptor in the rat basolateral amygdala and bed nucleus of the stria terminalis. 362:71-85.

Grenhoff J, Tung C-S, Svensson TH (1988) The excitatory amino acid antagonist, kynurenate, induces pacemaker-like firing of dopamine neurons in rat ventral tegmental area in vivo. Acta Physiol Scand 134:567-568.

Groenewegen HJ, Berendse HW (1990) Connections of the subthalamic nucleus with ventral striatopallidal parts of the basal ganglia in the rat. J Comp Neurol 294:607-622.

Hestrin S (1993) Different glutamate receptor channels mediate fast excitatory synaptic currents in inhibitory and excitatory cortical neurons. Neuron 11:1083-1091.

Hollmann M, Heinemann S (1994) Cloned glutamate receptors. Annu Rev Neurosci 17:31-108.

Iacopino A, Christakos S, German D, Sonsalla PK, Altar CA (1992) Calbindin-D $28 \mathrm{k}$-containing neurons in animal models of neurodegeneration: possible protection from excitotoxicity. Mol Brain Res 13:251-261.

Ito H, Goto S, Sakamoto S, Hirano A (1992) Calbindin-D $28 \mathrm{~K}$ in the basal ganglia of patients with Parkinsonism. Ann Neurol 32:543-550.

Johnson SW, Seutin V, North RA (1992) Burst firing in dopamine neurons induced by $N$-methyl-D-aspartate: role of electrogenic pump. Science 258:665-667.

Jonas P, Burnashev N (1995) Molecular mechanisms controlling calcium entry through AMPA-type glutamate receptor channels. Neuron 15:987-990.

Jonas P, Racca C, Sakmann B, Seeburg PH, Monyer H (1994) Differences in $\mathrm{Ca}^{+2}$ permeability of AMPA-type glutamate receptor channels in neocortical neurons caused by differential GluR-B subunit expression. Neuron 12:1281-1289.

Keinänen K, Wisden W, Sommer B, Werner P, Herb A, Verdoorn TA, Sakmann B, Seeburg PH (1990) A family of AMPA-selective glutamate receptors. Science 249:556-560.

Kikuchi S, Kim SU (1993) Glutamate neurotoxicity in mesencephalic dopaminergic neurons in culture. J Neurosci Res 36:558-569.

Kita H, Kitai ST (1987) Efferent projections of the subthalamic nucleus in the rat: light and electron microscopic analysis with the PHA-L method. J Comp Neurol 260:435-452.

Kornhuber J, Kim J-S, Kornhuber ME, Kornhuber HH (1984) The cortico-nigral projection: reduced glutamate content in the substantia nigra following frontal cortex ablation in the rat. Brain Res 322:124-126. 
Lange KW, Löschmann P-A, Sofic E, Burg M, Horowski R, Kalveram KT, Wachtel H, Riederer P (1993) The competitive NMDA antagonist CPP protects substantia nigra neurons from MPTP-induced degeneration in primates. Naunyn Schmiedebergs Arch Pharmacol 348:586-592.

Laurie DJ, Putzke J, Zieglgänsberger W, Seeburg PH, Tölle TR (1995) The distribution of splice variants of the NMDAR1 subunit mRNA in adult rat brain. Mol Brain Res 32:94-108.

Lavoie B, Parent A (1991) Dopaminergic neurons expressing calbindin in normal and parkinsonian monkeys. NeuroReport 2:601-604.

Llewellyn-Smith IJ, Pilowsky P, Minson JB (1993) The tungstatestabilized tetramethylbenzidine reaction for light and electron microscopic immunocytochemistry and for revealing biocytin-filled neurons. J Neurosci Methods 46:27-40.

Marey-Semper I, Gelman M, Lévi-Strauss M (1995) A selective toxicity toward cultured mesencephalic dopaminergic neurons is induced by the synergistic effects of energetic metabolism impairment and NMDA receptor activation. J Neurosci 15:5912-5918.

Martin D, Bustos GA, Bowe MA, Bray SD, Nadler JV (1991) Autoreceptor regulation of glutamate and aspartate release from slices of the hippocampal CA1 area. J Neurochem 56:1647-1655.

Martin LJ, Blackstone CD, Huganir RL, Price DL (1992) Cellular localization of a metabotropic glutamate receptor in rat brain. Neuron 9:259-270.

Martin LJ, Blackstone CD, Levey AI, Huganir RL, Price DL (1993) AMPA glutamate receptor subunits are differentially distributed in rat brain. Neuroscience 53:327-358.

Michaels RL, Rothman SM (1990) Glutamate neurotoxicity in vitro: antagonist pharmacology and intracellular calcium concentrations. J Neurosci 10:283-292.

Molnar E, Baude A, Richmond SA, Patel PB, Somogyi P, McIlhinney RAJ (1993) Biochemical and immunocytochemical characterization of antipeptide antibodies to a cloned GluR1 glutamate receptor subunit: cellular and subcellular distribution in the rat forebrain. Neuroscience 53:307-326.

Monyer H, Sprengel R, Schoepfer R, Herb A, Higuchi M, Lomeli H, Burnashev N, Sakmann B, Seeburg PH (1992) Heteromeric NMDA receptors: molecular and functional distinction of subtypes. Science 256:1217-1221.

Naito A, Kita H (1994) The cortico-nigral projection in the rat: an anterograde tracing study with biotinylated dextran amine. Brain Res 637:317-322.

Nakanishi S (1992) Molecular diversity of glutamate receptors and implications for brain function. Science 258:597-603.

Nusser Z, Mulvihill E, Streit P, Somogyi P (1994) Subsynaptic segregation of metabotropic and ionotropic glutamate receptors as revealed by immunogold localization. Neuroscience 61:421-427.

Olney JW, Ho OL, Rhee V (1971) Cytotoxic effects of acidic and sulphur containing amino acids on the infant mouse central nervous system. Exp Brain Res 14:61-76.

Ossowska K (1994) The role of excitatory amino acids in experimental models of Parkinson's disease. J Neural Transm 8:39-71.

Overton P, Clark D (1992) Iontophoretically administered drugs acting at the $N$-methyl-D-aspartate receptor modulate burst firing in A9 dopamine neurons in the rat. Synapse 10:131-140.

Paquet M, Soghomonian J-J, Smith Y (1995) Cellular and sub-cellular localization of glutamate receptors in midbrain dopaminergic neurones in the squirrel monkey. Soc Neurosci Abstr 21:348.

Petralia RS, Wenthold RJ (1992) Light and electron immunocytochemical localization of AMPA-selective glutamate receptors in the rat brain. J Comp Neurol 318:329-354.

Petralia RS, Wang Y-X, Wenthold RJ (1994a) The NMDA receptor subunits NR2A and NR2B show histological and ultrastructural localization patterns similar to those of NR1. J Neurosci 14:6102-6120.

Petralia RS, Yokotani N, Wenthold RJ (1994b) Light and electron microscope distribution of the NMDA receptor subunit NMDAR1 in the rat nervous system using a selective anti-peptide antibody. J Neurosci 14:667-696.

Phend KD, Rustioni A, Weinberg RJ (1995) An osmium-free method of epon embedment that preserves both ultrastructure and antigenicity for post-embedding immunocytochemistry. J Histochem Cytochem 43:283-292.

Reynolds ES (1963) The use of lead citrate at high $\mathrm{pH}$ as an electron opaque stain in electron microscopy. J Cell Biol 17:208-212.

Roberts RC, McCarthy KE, Du F, Okuno E, Schwarcz R (1994) Immu- nocytochemical localization of the quinolinic acid synthesizing enzyme, 3-hydroxyanthranilic acid oxygenase, in the rat substantia nigra. Brain Res 650:229-238.

Rosales MG, Flores G, Hernandez S, Martinez-Fong D, Aceves J (1994) Activation of subthalamic neurons produces NMDA receptor-mediated dendritic dopamine release in substantia nigra pars reticulata: a microdialysis study in the rat. Brain Res 645:335-337.

Rothman SM, Olney JW (1987) Excitotoxicity and the NMDA receptor. Trends Neurosci 10:299-302.

Sato K, Kiyama H, Tohyama M (1993) The differential expression patterns of messenger RNAs encoding non- $N$-methyl-D-aspartate glutamate receptor subunits (GluR1-4) in the rat brain. Neuroscience 52:515-539.

Sato K, Mick G, Kiyama H, Tohyama M (1995) Expression patterns of a glutamate-binding protein in the rat central nervous system: comparison with $N$-methyl-D-aspartate receptor subunit 1 in rat. Neuroscience 64:459-475.

Scarnati E, Proia A, Campana E, Pacitti C (1986) A microiontophoretic study on the nature of the putative synaptic neurotransmitter involved in the pedunculopontine-substantia nigra pars compacta excitatory pathway of the rat. Exp Brain Res 62:470-478.

Schwarcz R, Köhler C (1983) Differential vulnerability of central neurons to quinolinic acid. Neurosci Lett 38:85-90.

Schwarcz R, Du F, McCarthy KE, Okuno E, Roberts RC (1992) Immunohistochemical localization of 3-hydroxyanthranilic acid oxygenase $\left({ }^{3} \mathrm{HAO}\right)$ and kynurenine aminotransferase in astrocytes of rat substantia nigra. Soc Neurosci Abstr 18:1044.

Sesack SR, Pickel VM (1992) Prefrontal cortical efferents in the rat synapse on unlabeled neuronal targets of catecholamine terminals in the nucleus accumbens septi and on dopamine neurons in the ventral tegmental area. J Comp Neurol 320:145-160.

Seutin V, Verbanck P, Massotte L, Dresse A (1990) Evidence for the presence of $N$-methyl-D-aspartate receptors in the ventral tegmental area of the rat: an electrophysiological in vitro study. Brain Res $514: 147-150$.

Siegel SJ, Janssen WG, Tullai JW, Rogers SW, Moran T, Heinemann SF, Morrison JH (1995) Distribution of the excitatory amino acid receptor subunits GluR2(4) in monkey hippocampus and colocalization with subunits GluR5-7 and NMDAR1. J Neurosci 15:2707-2719.

Smith ID, Grace AA (1992) Role of the subthalamic nucleus in the regulation of nigral dopamine neuron activity. Synapse 12:287-303.

Smith Y, Hazrati L-N, Parent A (1990) Efferent projections of the subthalamic nucleus in the squirrel monkey as studied by the PHA-L anterograde tracing method. J Comp Neurol 294:306-323.

Smith Y, Wichmann T, DeLong MR (1994) Synaptic innervation of neurones in the internal pallidal segment by the subthalamic nucleus and the external pallidum in monkeys. J Comp Neurol 343:297-318.

Smith Y, Charara A, Parent A (1996) Synaptic innervation of midbrain dopaminergic neurons by glutamate-enriched terminals in the squirrel monkey. J Comp Neurol 364:231-253.

Sonsalla PK, Nicklas WJ, Heikkila RE (1989) Role for excitatory amino acids in metamphetamine-induced nigrostriatal dopaminergic toxicity. Science 243:398-400.

Spreafico R, Frassoni C, Arcelli P, Battaglia G, Wenthold RJ, De Biasi S (1994) Distribution of AMPA selective glutamate receptors in the thalamus of adult rats and during postnatal development: a light and ultrastructural immunocytochemical study. Dev Brain Res 82:231-244.

Standaert DG, Testa CM, Young AB, Penney Jr JB (1994) Organization of $N$-methyl-D-aspartate glutamate receptor gene expression in the basal ganglia of the rat. J Comp Neurol 343:1-16.

Starr MS (1995a) Antiparkinsonian actions of glutamate antagonistsalone and with L-DOPA: a review of evidence and suggestions for possible mechanisms. J Neural Transm 10:141-185.

Starr MS (1995b) Glutamate/dopamine $\mathrm{D}_{1} / \mathrm{D}_{2}$ balance in the basal ganglia and its relevance to Parkinson's disease. Synapse 19:264-293.

Stone TW, Perkins MN (1981) Quinolinic acid: a potent endogenous excitant amino acid receptors in CNS. Eur J Pharmacol 72:411-412.

Svensson TH, Tung CS (1989) Local cooling of the prefrontal cortex induces pacemaker-like firing of dopamine neurons in rat ventral tegmental area in vivo. Acta Physiol Scand 136:135-136.

Tong Z-Y, Overton PG, Clark D (1996) Stimulation of the prefrontal cortex in the rat induces patterns of activity in midbrain dopaminergic neurons which resemble natural burst events. Synapse 22:195-208.

Tremblay M, Salin P, Soghomonian J-J (1995) Effect of 6-OHDA lesions 
on striatal mRNA levels encoding for glutamate receptor subunits. NeuroReport 6:2225-2229.

Trussell LO, Raman IM, Zhang S (1994) AMPA receptors and rapid synaptic transmission. Semin Neurosci 6:71-79.

Turski L, Stephens DN (1992) Excitatory amino acid antagonists protect mice against MPP+ seizures. Synapse 10:120-125.

Turski L, Bressler K, Rettig K-J, Löschmann P-A, Waxhtel H (1991) Protection of substantia nigra from MPP + neurotoxicity by $N$-methylD-aspartate antagonists. Nature 349:414-418.

Wang T, French ED (1993) Electrophysiological evidence for the existence of NMDA and non-NMDA receptors on rat ventral tegmental dopamine neurons. Synapse 13:270-277.
Westbrook GL (1994) Glutamate receptor update. Curr Opin Neurobiol 4:337-346.

Wu H-Q, Schwarcz R, Shepard PD (1994) Excitatory amino acidinduced excitation of dopamine-containing neurons in the rat substantia nigra: modulation by kynurenic acid. Synapse 16:219-230.

Yamada T, McGeer PL, Baimbridge DG, McGeer EG (1990) Relative sparing in Parkinson's disease of substantia nigra dopamine neurones containing calbindin-D 28K. Brain Res 526:303-307.

Zhang J, Chiodo LA, Freeman AS (1994) Influence of excitatory amino acid receptor subtypes on the electrophysiological activity of dopaminergic and nondopaminergic neurons in the rat substantia nigra. J. Pharmacol Exp Ther 269:313-321. 